\title{
An Update on Pathophysiology and Medical Management of Endometriosis
}

\author{
Kulvinder Kochar Kaur1, Gautam Allahbadia ${ }^{2}$ \\ ${ }^{1}$ Department of Obstetrics and Gynaecology (Reproductive Neuroendocrinology and Infertility), Dr. Kulvinder \\ Kaur Centre for Human Reproduction, Jalandhar, India \\ ${ }^{2}$ Rotunda-A Centre for Human Reproduction, Mumbai, India \\ Email: kulvinder.dr@gmail.com,drallah@gmail.com
}

Received 24 February 2016; accepted 21 May 2016; published 24 May 2016

Copyright (C) 2016 by authors and Scientific Research Publishing Inc.

This work is licensed under the Creative Commons Attribution International License (CC BY).

http://creativecommons.org/licenses/by/4.0/

c. (i) Open Access

\begin{abstract}
Endometriosis is an inflammatory oestrogen dependent disease defined by the presence of endometrial glands and stroma at extrauterine sites. The modern advance in treatment of endometriosis management is tackling the debilitating pain it causes, besides the infertility in patients desiring fertility in reproductive age group. This can be achieved by surgical or medical means, although in most cases a combination of both treatments is required. Usually, long term treatment is required in most cases. Unfortunately in most cases, pain symptoms recur between 6 months and 12 months once treatment is stopped. A lot of research has gone in understanding the pathogenesis and further medical management of endometriosis besides surgery to be useful in relieving pain and use in patients desiring fertility besides hormonal treatments used earlier like hormonal contraceptives (oral, transdermal or vaginal administration), progestogens, danazol, Gonadotrophic releasing hormone agonist (GnRH), aromatase inhibitors. Newer agents like antiangiogenic drugs, phytochemical agents like resveratrol, TNF- $\alpha$ inhibitors, GnRH antagonists like egalogolix, statins, antiinflammatory agents like COX2 Inhibitors and PPAR $\gamma$ inhibitors like pioglitazone etc., with recent work of combined efficacy of telmesartan of both PPAR $\gamma$ partial agonism along with angiotensin 1 receptor agonism having more efficacy, role of immunomodulators like rapamycin, lipoxin 4 and pentoxyphylline, GnRH antagonists like egalogolix are still under study undergoing phase III trials although preliminary results show promising results with fewer side effects as compared to similar duration of GnRH agonist and much less BMD side effects. Increasing number of trials show the safety of SPRM's, along with efficacy although disadvantage is suppression of fertility so cannot be used for women desiring fertility. Currently, only mifepristone and ulipristal have received FDA approval for indication in fibroid treatment, MTP and not for endometriosis as yet. The advantages and disadvantages of all the recent advances are discussed in an update in the pathophysiology as well medical treatment of endometriosis.
\end{abstract}

\section{Keywords}

Antiangiogenic Agents, Phytotherapeutics Drugs (Resveratrol), PPAR Gamma Agonism with AT1R, 
Agonism (Telmesartan), GnRH Antagonist (Elagolix), IL-17A, SPRM Modulators (Ulipristal), Immunomodulators (Pentoxyphylline), Statins (Atorvastatin)

\section{Introduction}

\subsection{Endometriosis}

Endometriosis is a benign disease which is characterized by the presence of endometriotic lesions, consisting of functional endometrial glands and stroma outside the uterine cavity [1]. The prevalence of the disease is high ranging from $6 \%-10 \%$ of women of reproductive age group and it affects significantly on the annual costs in the heallh care systems [2]. It may cause a broad spectrum of pain symptoms ranging from no symptoms to severe dysmenorrhoea, dyspareunia, dyscachexia, chronic pain [3] and in fertility [4] [5], which leads to a severely limited quality of patients private and professional life [6].

The disparate morphological, histologic, and biologic properties of endometriotic lesions [7] suggest that it should be considered a collection of related conditions, broadly based on the location of the lesion and split into peritoneal, ovarian and rectovaginal septum endometriosis (RVS) [8]. Significantly, more nerve fibres are present on the peritoneal wall of women with endometriotic lesions compared with women without the condition [9]. Mckinnon et al. reported that presence of endometriosis associated nerve fibres appear to be related to both the pain experienced by women with endometriosis and the concentration of follicular fluid cytokines, however this association varies with the lesion/location e.g. rectovaginal septum lesions are significantly more commonly associated with nerve fibres along with higher peritoneal fluid glycodelin concentrtions. [10]. The main purpose of endometriosis management is alleviating pain associated with the disease. This can be done by medical or surgical means, although in most women a combination of both is required [11]. Long-term treatment is needed in most women; unfortunately in most women pain symptoms recur between 6months to 12 months once treatment is stopped. Current medical treatments have been based on two mechanisms 1) antiinflammation and 2) hormonal [12]. Nonsteroidal antiinflammatory drugs (NSAIDS) are used in women with dysmenorrhea, although there is not enough evidence to support their effectiveness [13].

The exact cause of endometriosis remains unknown, but the widely accepted pathogenesis theory infers that endometrial debris transplanted by retrograde menstrual flow adhere and implant on peritoneum and local organs leading to endometriotic lesions [14]. A complex series of events like local invasion, cell attachment and proliferation supported by hormonal and immunologic responses, inflammation and neogenesis result in disease establishment [15]. Although most women experience retrograde menstruation, only 10\% - 15\% develop endometriosis. Santuli et al. showed that the expression of enzymes implicated in the regulation of the sphingosine 1 phosphate level balance and its receptors were heavily dysregulated in endometriotic lesions in favour of a decrease sphingosine- 1 phosphate catabolism. They proposed for a role for sphingosine pathway in establishing and survival of endometriotic lesions [16].

\subsection{Pathophysiology}

The major proinflammatory cytokines/transcription factors axis' is the crossroads of the molecular pathway involved in the fundamental aspects of the pathophysiology of endometriosis. There is a rich and intricate interconnection that exists among them. Cytokines e.g. TNF $\alpha$ and interleukin- $1 \beta$ released by peritoneal macrophages and ectopic endometrial cells activate the transcriptional factors, such as nuclear factor kappaB (NF $\kappa$ B) and activator protein 1 (AP1). Active transcription factors bind to the DNA of ectopic and endometriotic cells and induce transcriptional activity of genes which encode the following proteins.

Other cytokines like IL6, IL8, macrophage migration inhibitory factor(MIF), Monocyte chemoattractant protein 1(MCP1), granulocyte, macrophage colony stimulating factor(GM-CSF), TNF- $\alpha$, IL-1beta themselves, IL4 [17]-[20], Nitric oxide(NO) and vascular endothelial growth factor(VEGF), the most prominent proangiogenic factor sin endometriosis [21] see Figure 1 for pathogenesis (courtesy ref. [22]).

Various immunological aspects also play an important role in the pathogenesis of endometriosis, whereby the disease shows marked similarities with autoimmune diseases [23]. Thus it was shown in the course of endometriosis autoantibodies against endometrial antigens such as e.g. transferrinor $\alpha-2+$ HS glycoprotein are formed, and 


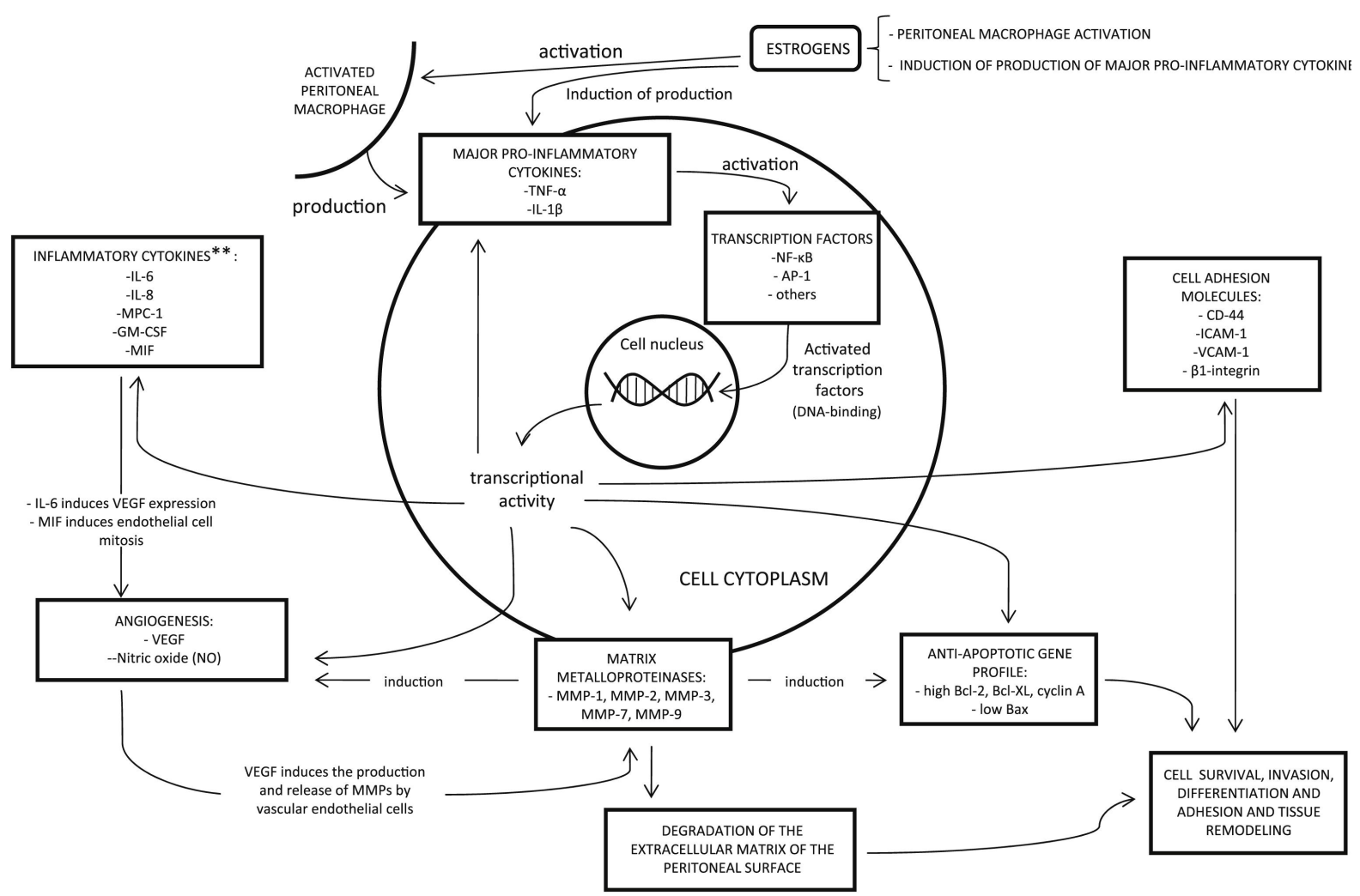

Figure 1. Courtesy ref22-Amodel of the most relevant molecular pathways in epithelial and stromal ectopic endometrial cells involved in the pathophysiology of endometriosis.*Major proinflammatory cytokines are produced in both peritoneal macrophages and endometriotic cells **Altered peritoneal cell mediated immunity seen in endometiosis is related to inflammatory cytokine expression profile (Source ref [1]-[9]).

can often be responsible for the infertility frequently encountered in endometriosis patients [24] [25]. Also concentrations of fluctuations of cytotoxic and activated $\mathrm{T}$ lymphocytes in peripheral blood during menstrual cycle appear to play a certain role. The fluctuations of regulatory T cells (Treg) detected during endometriosis can be attributed to changed immune response [26]. Endometriosis is characterized by a chronic inflammatory reaction with elevated concentration of inflammatory cytokines in serum and peritoneal fluid [27]. Elevated numbers of macrophages, dendritic cells, and natural killer (NK) cells seen in the peritoneum, for some unknown reason are not able to recognize and degrade the endometrium tissue scattered in the abdominal cavity [28]. This chronic inflammatory reaction, in turn leads to an increased production of reactive $\mathrm{O} 2$ species [29]. The basal part of endometriosis contains endometrial stem cells and progenitor cells [30], which explain the high regeneration potential of this tissue. Even extra uterine circulating stem cells and progenitor cells from bone marrow contribute considerably to the formation of endometriosis lesions [30]. These stem cells can reach abdominal cavity via retrograde manner in an assumption supported on the assumption that glandular cells of some endometriosis lesions are of monoclonal in origin [31].

A major prerequisite for long term survival of endometriois is angiogenesis. Only in this way can the scattered endometriosis tissue which is ischemic outside the uterus, be adequately supplied with $\mathrm{O}_{2}$ and nutrients. Because of this early stage of endometriosis lesions are reddish, caused by a high density of red blood vessels and vessel dilatations [32] [33]. Numerous angiogenic growth factors identified including VEGF, which is produced and released in increased amounts in endometriosis, regulates the in growth of new blood vessels in endometriotic lesions [34]. Endometrium in patients with endometriosis already exhibits an elevated angiogenic activity, which can favour the creation of new endometriotic lesions [35]. Endometriosis thus belongs to the group of angiogenic diseases along with rheumatoid arthritis, psoariasis, diabetic retinopathy as well as tumor growth and metastasis [35]. Hence, mechanisms governing new blood vessels formation to develop targeted antiangiogenic therapies has been the goal [36] [37]. Other experimental agents affecting angiogenesis like growth 
factor inhibitors, endogenous angiogenesis inhibitors, fumagillin analogues, statins. COX2 inhibitors, phytotherapeutic agents, immunomodulators, dopamine agonists have been studied [38].

Pain can occur due to long term cyclic bleeding of oestrogen dependent endometriotic lesions with consecutive inflammatory reaction as well as irritation and invasion of pelvic nerves [39]. Pain transmitting nerve fibres can grow together into endometrioic lesions as shown recently [40], which is also known as "neuroangiogenesis". These nerve fibres in turn increase the pain sensation of the CNS [41]. If it was possible to develop as shown in animal experiments [42], to inhibit this process by targeted drug measures, one should be able to in future develop appreciably more effective pain therapies having considerably fewer side effects than conventional hormonal treatment options.

Ahn et al. studied the role of IL-17A, another emerging potent angiogenic, proinflammatory cytokine involved in the pathophysiology of severe chronic inflammatory conditions like rheumatoid arthritis, psoariasis, in endometriosis. They demonstrated the potential implication of IL-17A in the pathogenesis and pathophysiology of endometriosis. They showed a differential expression of IL-17A primarily in human ectopic endometrial lesions and matched ectopic endometrium from women with endometriosis. Surgical removal of lesions resulted In a significant decreased IL-17A concentrations. Immunohistochemistry revealed localization of IL-17A primarily in stroma of matched ectopic and eutopic tissue sample. In vitro stimulation of endometrial carcinoma, Ishikawa cells and HUVEC's with IL-17Arevealed significant increase in angiogenic (VEGF and IL8), proinflammatory (IL-6, and 1L-1beta) chemotactic cytokines (G-CSF, CXCL2, CXCL-1 \& CXC3C1). IL-17A promoted tubulogenesis of HUVEC's platedon Matrigel, in a dose dependent manner. This was the first study proving that endometriotic lesions produce $1 \mathrm{~L}-17 \mathrm{Aand}$ that removal of endometriosis laparoscopically leads to significant decrease in systemic levels of IL-17A. This proves important role of IL-17A in promoting angiogenesis as well as proinflammatory environment in peritoneal cavity for the establishment and maintenance of endometriotic lesion [43].

Matrix mataloproteinase (MMP's)-MMP1, MMP2, MMP3, MMP7, MMP9 are involved in the degradation and remodeling of the extracellular matrix of the peritoneal surface [20] [21] [44] [45].

Increased antiapoptotic gene profile [44] [46] [47]

Adhesion molecule such as CD44s (a cell surface glycoprotein involved in the adhesion of endometrial cell to peritoneal mesothelial cells, intercellular adhesion molecule1 (ICAM1), and vascular cell adhesion molecule1 (VCAM1) [20] [21] [44].

Therefore, the definition of therapeutic agents as "antiinflammatory", "immunomodulators" or "inducers of apoptosis" is too basic a criteria especially if it relates both to major proinflammatory cytokines /transcription factor axis. But for the sake of organization, some sort of classification is needed.

\subsection{Management}

The approaches used for the treatment of endometriosis currently involve pharmacologic tharapies and surgical removal of endometriotic implants. Because proliferation along with longterm survival of ectopic endometrium is oestrogen dependent [48], classic pharmacologic therapies are aimed at suppressing endogenous Oestrogen application of OC's, GnRH agonist, androgenic agents or aromatase inhibitors [49]. Besides being associated with marked side effects which limit prolonged exposure, recurrence, is the biggest problem following treatment cessation [50].

Early developing lesions which are the most active areas have typically pink-red appearance, because of their higher vascular density [51]. 1) They also exhibit increased number of pericyte free immature free, compared with the blood vessels of the later stage lesions 2) the peritoneum from patients with endometriosis contain higher amounts of angiogenic growth factors and reduced concentration of antiangiogenic compounds [34]. 3) The eutopic endometrium from patients with endometriotic lesions has been shown to exhibit increased angiogenic potential, as compared to healthy women [52].

\section{Role of Anti Angiogenic Factor}

\subsection{Growth Factor Inhibitors}

One of the most studied angiogenic factors is the vascular endothelial growth factor (VEGF). Highly active red endometriotic lesions contain in the highest concentration of VEGF as compared to other lesions type [53]. Be- 
sides, peritoneal fluid concentration of VEGF correlates significantly with the stage of endometriosis [54]. VEGF is a dimer glycoprotein, with its biological effects mediated by two of its high affinity receptor tyrosine kinase on the surface of micro vessels, endothelial cells i.e. VEGFR1 (Flt1) and VEGFR (KDR/Flk1). Hull et al. first reported in 2003, the treatment with both Flt1 receptor and an affinity purified VEGF significantly inhibited the growth of developing endometriotic lesions in nude mice by disrupting their immature microvasculature [55]. Subsequently Nap et al. 2004, 2005 [56] [57] recapitulated similar results, while treating nude mice with an antiVEGF antibody in the nude mouse model and in chicken chorioallantoic membrane (CAM) assay. Although these findings prove that blockade of VEGF signaling prevents the establishment of endometriotic lesions, the development of anti VEGF antibody in vitro has proved to be efficacious in preventing the establishment of endometriotic lesions. Although bevacizumab, demonstrates antiendometriotic actions, its clinical application appear to be limited because of severe side effects, which include hypertension, proteinuria, haemorrhage, thrombosis and gastrointestinal perforation [58].

The most potent stimulus for the upregulation of VEGF is hypoxia which prevents the intracellular degradation of ubiquitously expressed hypoxia inducible factor $1 \alpha$ (HIF-1 $\alpha$ ) [59]. Under hypoxic conditions, the factors translocate into the nucleus, hetrodimerizes with HIF-1 $\beta$ and hydrocarbon nuclear receptors translocates and binds to the hypoxia response element (HRE) on the gene encoding VEGF [60]. Accordingly Sharkey 2000 showed that VEGF secretion from hypoxia exposed endometrial and stromal and platelet cell cultures [58]. Becker et al. 2008 reported that targeting the hypoxia mechanism represents another option to block VEGF signalling of endometriosis [61]. In fact they found that HIF1 $\alpha$ is upregulated in surgically induced peritoneal and mesenteric endometriotic lesions. In mice promoting the increased expression of VEGF treatment with 2 methoxy estradiol — an antiangiogenic agent, currently being tested in phase II trials for cancers [62], dose dependently inhibits this process and suppresses lesions with administration of high doses [63]. However to its extensive first pass metabolism and low solubility, subtherapeutic plasma concentrations of 2 methoxyestradiol have been observed despite large orally administered dose [64]. First these major pharmacokinetic properties have to be solved before 2 methoxyestradiol can be successfully launched.

Because endometriosis not only expresses VEGF, but also various other growth factors, hence development of new blood vessels in endometriotic lesions is crucially dependent on interaction of multiple signalling pathways (Figure 2).

Laschke et al. 2006 [38] studied the effect of combined growth factor inhibition on the vascularization of the endometriosis in the dorsal skin fold chamber of Syrian hamsters [38]. This model allows for the detail study of angiogenesis and microvascular network morphology, endometriotic lesions, by means of intravital fluorescence. Endometriotic lesions were treated with small molecule tyrosene kinase inhibitors SU 5416, which solely suppresses the activity of VEGF receptor tyrosine kinase, or SU6668 which is a multipotent inhibitor of the tyrosine kinase activity VEGF, basic fibroblast growth factor (bFGF), and a platelet derived growth factor receptor [65]. The combined inhibition of all 3 growth factors was much more effective in suppressing lesional vascularization and growth, than blockade of VEGF alone [66]. These findings indicate that antiangiogenic compounds which target simultaneously different growth factor signalling, may be highly effective in the future of antiangiogenic therapy of endometriosis.

\subsection{Role of Prokineticins}

Women with various benign gynaecologocical disorders like endometriosis show decreased endometrial receptivity, along with abnormal expression of endometrial biomarkers [67]. Wei et al. recently reported reduced expression of putative biomarkers of implantation -pointing to an abnormal epithelial function in women with endometriosis [68]. Hence, Tiberi et al. studied PROK1mRNA expression by real time PCR in endometrium of 12 healthy as well as 12 eutopic endometrium of women with endometriosis and found PROK1 mRNA was decreased in 4/12 (33\%) samples of endometriosis in contrast to being present in 10/12 (83\%) from normal women which indicated PROK1, an angiogenic factor is implicated in the vascular function of periimplantation endometrium and pregnancy and an altered expression ofPROK1 could be one of several biochemical abnormalities characterizing eutopic endometrium of endometriosis [69]. They further studied the in vitro steroid hormone dependence of PROK1, mRNA, and since endometrial stromal cells (ESC'c) are involved in implantation, they evaluated PROK1 expression during in vitro differentiation in decidual phenotype with the critical genes identified for decidualization being PR, Homeobox10 (HOXA10) [70], with PR playing a role in repression of deci- 


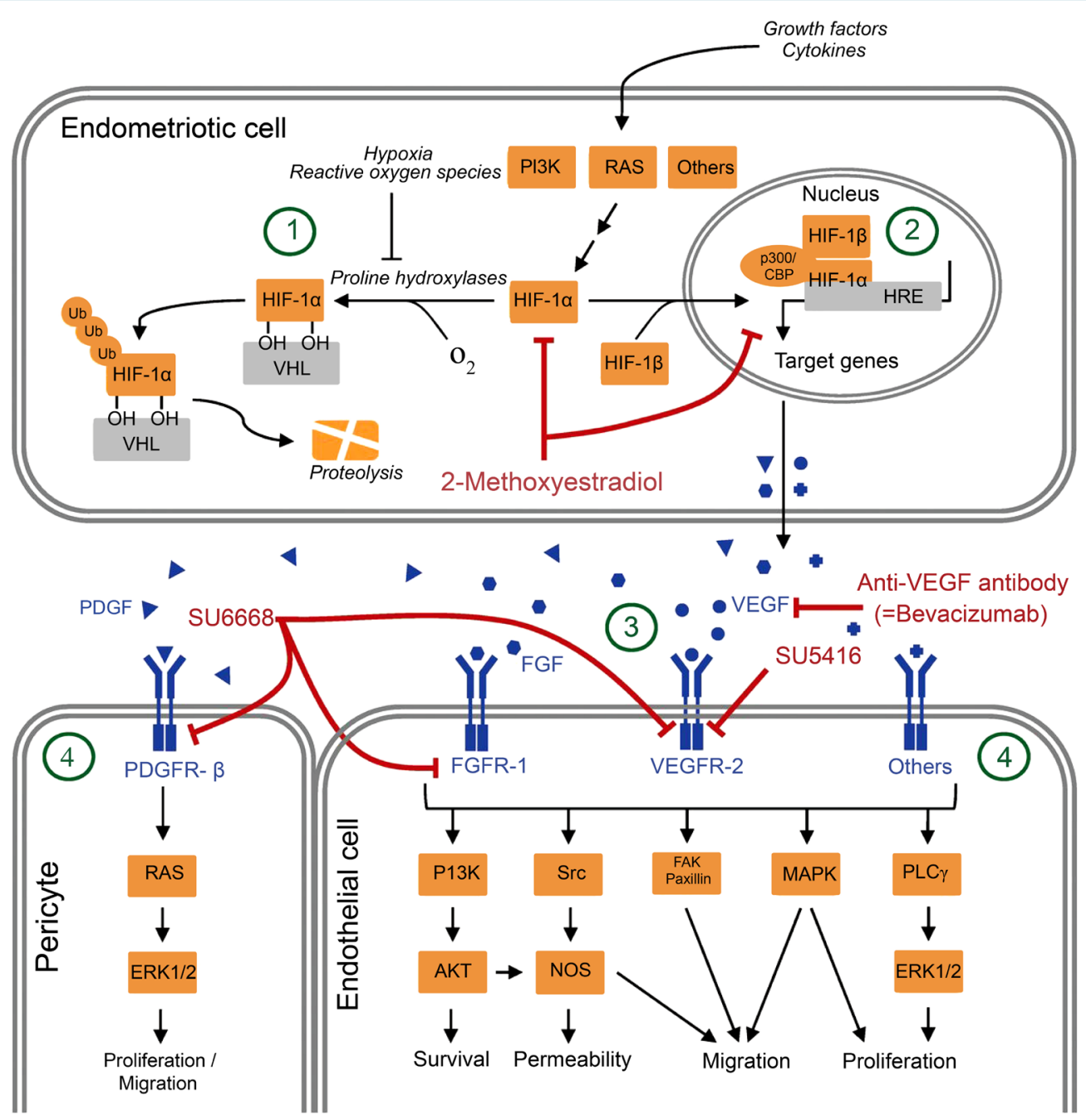

Figure 2. Courtesy ref no 28-angiogenic pathways in endometriosis and specific targets of growth factor inhibitor ,which have been shown to exert anti-angiogenic effects on endometriotic lesions, i.e. anti VEGF antibody (bevacizumab), 2 methoxyestradiol,, SU5416 and SU6668. Under hormonal HIF-1- $\alpha$ is hydroxylated following rapid VHL dependent proteolysis (1). Under hypoxiathe proiline hydrolases are no longer active. HIF-1- $\alpha$ translocates to the nucleus, where it targets genes (via HRE) encoding multiple proteins, including angiogenesis, growth factors (2). These growth factors are secreted by into the extracellular space where they bind to specific receptors located on the surface membrane of endothelial cells and pericytes (3). This leads to the activation of various intracellular signalling pathways, which regulate cell survival, proliferation, migration as well as vascular permeability (4). AKT, active human protein kinase ERK, extracellular signal regulated kinase: FAK; focal adhesion kinase. FGF, fibroblast growth factor, FGFR, fibroblast growth factor receptor; HIF, hypoxia inducible factor; HRE, hypoxia response element; MAPK, mitogen activated protein kinase; NOS, nitric oxide synthase; p300/CBP, p300/CREB binding protein; PDGF, platelet derived growth factor; PDGFR, platelet derived growth factor receptor; PI3K, phosphatidylinositol-3-kinase, PLC $\gamma$, phospholipase C gamma; RAS, rat sarcoma GTPase; Src, tyrosine kinase Ub, Ubiquitin; VEGF, Vascular endothelial growth factor; VEGFR, vascular endothelial growth factor receptor; VHL, von Hippel-Lindad protein.

dual transformation. The expression of these specific genes is inversely correlated with cellular PR levels and HOXA10, a member of the homeobox gene family which is known to be essential in, embryo development [71] [72]. Tiberi et al., extending the previous studies, studied PROK1 mRNA, HOXA10, PR mRNA in primary cultures of ESC from eutopic endometrium of 12 endometriotic patients along with 12 controls to study whether the in vitro steroid hormone dependence of PROK1 gene expression is altered in endometriotic ESC obtained from women with endometriosis in contrast to normal women and they found PROK1 and PR expression was 
not induced after 1:4 days of treatment with steroid hormones. However, when ESC from both groups of women were differentiated for decidual phenotype, PROK1 mRNA was upregulated and HOXA10 mRNA are downregulated to some extent and especially these results point to $\mathrm{P}$ resistance to some extent in cases of endometriosis [73].

But having reviewed the role of prokineticins/EG-VEGF in angiogenesis in reproduction especially during hypoxic conditions like pregnancy where HIF1 $\alpha$ binds to the promoter of EG-VEGF and PROKR1 leads to upregulation of these genes in placenta, Lee et al. compared the expression of VEGF/PROK1, its receptors, PROKR1 and PROKR2 in eutopic endometrium, infertile ectopic endometrium tissue in 15 infertile patients diagnosed to have endometriosis by laparoscopy for tubal testing. On quantitative PCR analysis of genes in eutopic and ectopic endometrial tissue, EG-VEGF mRNA expression studied by immunohistocytochemistry was found to be 50 fold higher in the secretory endometrium as compared to proliferative phase. PROKR1 was 6 fold higher in the latter as compared to the former. PROKR2 trascript was found in proliferative but not in secretory endometrium. In patients with endometriosis, eutopicendometrial PROKR2 transcripts were 4 fold higher in proliferative than secretory phase. Although no difference was found in EGVEGF/PROKR1 in proliferative vs secretory endometrium in these patients, no difference was found in PROK1/in eutopic endometrium of normal womenand in women with endometriosis. In Paired laser captured microdissected eutopic endometrium and ectopic endometrium of endometriotic sample, a significantly higher EG-VEGF, but not VEGF transcript levels was detected in the ectopic when compared with eutopic samples; although expression of PROKR1 and PROKR2 were barely detectable. Hscoring confirmed that stroma of endometriotic samples had a significantly higher EG-VEGF protein expression than eutopic endometrium which confirms it is not VEGF but EG-VEGF which may play an important role in angiogenesis in endometriosis and one has to plan newer antiangiogenic strategies targeting PROK1 [74].

\subsection{Role of Phytotherapeutic Agent Resveratrol}

Resveratrol (trans 3'5'4' tri hydroxystilbasic) is a phytochemical compound of grapes, redwines and berries which has been shown to act as a pleiotropic agent, affecting multicellular processes including proliferation, apoptosis, O2 radical formation. It dose dependently stops the development of new blood vessel formation [75]. In fact, resveratrol has been shown to inhibit hypoxia mediated activated RK1/2and Akt resulting in decreased expression of HIF- $\alpha$ and VEGF [76] [77]. Also it reduces activity of MMP2and 9 [78] [79], which are both involved in ECM disruption in the early angiogenic phase of vascular bedand sprout formation [80]. In addition resveratrol directly inhibits proliferation and migration of endothelial cells and vascular smooth muscle cells [81]. Brinner Trati 2014 reported in nude micetransplantation of endometrioic tissue into peritoneal cavity was inhibited by oral gavage of resveratrol [82]. Aush et al tried to study whether resveratrol suppresses the development of new microvessels in endometriotic lesions by inhibiting endothelial cell proliferation. In a mouse model of endometriosis20 BALB c mice with surgically induced endometriosis were treated with rasveratrol (40 $\mathrm{mg} / \mathrm{kg} /$ day, $\mathrm{n}=10$ orvehicle $\mathrm{n}=10 \times 4$ weeks) and found angiogenic peritoneal and mesenteric endometriotic lesions as indicated by a marked decrease in microvessel density as compared to control. Immunocytochemical chemical analysis revealed this was caused by a decreased proliferation activity of CD31 positive endothelial cells in the newly developed microvasculature of the lesions. Also lesions in resveratrol treated mice exhibited a reduced growth rate and smaller final size than controls which was associated with lower number of proliferating cell nuclear antigen (PCNA) andKi67 positive stromal and glandular cells. Apoptotic cells were not detectable in either group. Thus it was concluded that rasveratrol is a potent inhibitor of vascularization in endometriotic lesions and most probably causes suppression of lesions, growth and represents a promising candidate therapy for future phytochemical treatment of endometriosis. Although limitations were surgical tissue transplantation without use of pathological endometrial tissue of humans, results may not fully correlate to human endometriosis [83].

\subsection{Role of Statins}

Statins are lipid lowering agents that have been shown to have antiangiogenic activities in high doses [84]. Studies on atorvastatin have demonstrated antiangiogenic activity in endometriotic lesions without side effects on reproductive function [85] [86]. However, Vitagilano et al. on the basis of systematic review of literature selected 24 articles of in vivo and in vitro performances on human and animal models of statins in which 12 re- 
garding their effects on ovarian function and fertility. All articles seemed to emphasize on the utility of statin administration in treatment of endometriosis due to their antiproliferative, proapoptotic effects, their ability to reduce cellviability and migration and inhibition of angiogenesis and anti-inflammatory activities. As far as the adverse effects on gonadal activities, steroidogenesis and fertility function, no conclusive data were concluded in human models (excluding women with PCOS) in which significant decline of androgen levels as reported by studies conducted in vitro as well as in vivo in animal models. Despite evidence supporting statins as the potential therapeutic agents for a target conservative treatment for endometriosis, the uncertainties regarding their impact on gonadal function maynot define them as an approach to therapy for young fertile women [87].

\subsection{Role of Dopamine Agonists}

With the work of Basu et al. that dopamine selectively inhibits VEGF it started getting used for prevention of OHSS and simultaneously the group of Novella Maestra 2009 used cabergoline over 14 days and found it caused regression of endometriotic lesionsby suppressing cell proliferation as well as VEGF mediated angiogenesis. Cabergoline treatment significantly lowers expression of VEGF and VEGFR2 in endometriotic lesions [88]. The only limitation was cabergoline treatment is known to be associated with increased incidence of cardiac valve regurgitations [89]. Hence, they compared efficacy of nonergot derived dopamine agonist quinagolide with that of cabergoline, inhibiting angiogenesis and vascularization of endometriotic lesions [90]. Because both were equally effective they conducted a pilot study with quinagolide in hyperprolactinemic patients who required first surgical intervention and underwent a second look laparoscopy [91]. Treatment with quinagolide induced a 70\% reduction of endometriotic lesions, with 35\% vanishing completely. Histological analysis revealed that this was associated with downregulation of VEGF/VEGFR2 proangiogenic cytokines and plasminogen activator1 within the lesions. Further, larger clinical trials are warranted with quinagolide with the promising results they offer. We studied a comparative analysis of cabergoline, atorvastatin, GnRH antagonist ketoconazole in a small group of patients after these initial reports and found caberline and atorvastatin to be effective in mild to moderate endometriosis but ketoconazole was not effective [92].

\section{Role of TNF $\alpha$ Inhibitors}

TNF $\alpha$ (an inflammatory cytokine) is a potent transducer of transcriptional factors which determine the production of proteins that coordinate the pathophysiology of endometriosis. Specific TNF $\alpha$ blockers of general antiinflammatory agents, may interfere with this process. Soluble TNF $\alpha$ receptor1, also known as TNF $\alpha$ binding protein or TRP has been demonstrated to block the transcription of inflammatory cytokines involved in the immortalized $12 \mathrm{Z}$ epithelial endometrial cell lines [4]. Thus human endometrial stromal cells [hESC's] cultures siRNAs that silence the TNF $\alpha$ gene was to determine the expression of IL8 and genes that inhibited apoptosis, which are major markers of TNF $\alpha$ activated NF $\kappa$ B pathway [93].

Etarnerceptis a fusion protein consisting of human recombinant soluble TNF receptor ( $\mathrm{p} 75$ ) conjugated to a human Fc antibody subunit with neutralizing TNF activity. It is used for rheumatoid arthritis, juvenile rheumatoid arthritis, psoriatic arthritis with no known serious adverse effectswith long term usage .In vitro enhanced proliferation observed in epithelialcells and Hesc's cultured with peritoneal fluid from patients has been shown to be significantly inhibited by etarnercept [94]. The effects of etarnercept on a rat model on endometriotic implants were evaluated in a randomized controlled study [95]-[98], and animals showed significant changes in the volume of lesions, histopathologicalscore and molecular parameters, such as serum levels of VEGF, IL-6, \& TNF- $\alpha$. Inflinimab (a monoclonal antibody against TNF $\alpha$ [98], produced the same effects. Both infliximab and etanercept reduced endometriotic implants, plasma NO levels, while the levels of asymmetric dimethyl arginine (ADMA), an endogenous Nitric oxide synthase (NOS) antagonist were increased. Use of etanercept in spontaneal peritoneal endometriosis in baboons was tested in a randomized controlled blinded study including 12 animals that received etanercept or placebo [99]. In spite of spiral sample; size, stat decrease in red lesions was noted in the treatment group surface area. The efficacy of c5N, a specific antiTNF $\alpha$ monoconol antibody (mAb) in the reduction of established lesions in experimental endometriosis induced in baboons was also tested in a randomized controlled study in baboons [100]. Laparoscopic controls were made, the moment medication was administered and 25 Days after treatment. The Ab Significantly decreased and the total number of surface and volume of endometriosis like lesions, mainly through a reduction in the most active red lesions. No impact was found in the menstrual cycle. Later the same animals included in this study were resubmitted to IV doses of c5N 
and 2 of them died of unspecified causes.

A small randomized controlled trial has been published using infliximab, a monoclonal anti-TNF- $\alpha$ antibody [101]. 21 patients with severe pain and rectovaginal nodule were randomized to receive infliximab prior to surgery but no differences were found in the pain scores among both groups. Three adverse effects were reported in the infliximab grou.1 case of acute tonsillitis, one case of mild infusion reaction and one case of acute leukaemia. There is not enough evidence to recommend the use of antiTNF- $\alpha$ drugs for treatment of pain associated with endometriosis, with more RCT's required for recommending any newer drugs [102].

\section{Role of GnRH Antagonists}

Elagolix is anoral short acting GnRH antagonist that unlike injectable GnRH antagonists produces dose dependent suppression of pituitary and ovarian hormones in women. It produces partial ovarian suppression at lower doses and full suppression at higher doses. In a randomized double blind placebo control Phase II trial Diamond MP et al. 2014 studied elagolix treatment with $150 \mathrm{mg}, 250 \mathrm{mg}$ daily or placebo and found these significantly suppressed dysmenorrhea, dyspareunia during first weeks of treatment. It had an acceptable efficacy and safety profile. Minimal bone mineral densitychanges were observed with—over 24 weeks of elagolix but this was lower as compared to 3 months treatment of the GnRH agonist leuprolide. Adverse effects are consistent with its mechanism of action of Oestrogen (E2) supression and consist of headache, anxiety, nausea and are usually mild to moderate. Although it is a potential strategy for achieving partial E2 induced suppression in women with endometriosis related pain with an acceptable safety profile, additional studies are warranted and presently there is no one evidence to approve GnRH antagonists for endometriosis associated pain [103].

\section{Selective Progesterone Receptor Agonists (SPRM)}

SPRM's are defined as the class of progesterone receptor (PR) ligands which exhibit both agonistic and antagonistic [104], reviewed in detail for treatment of uterine fibroids]. Although results of studies of PRM in women are promising [105] [106], they are not used routinely as they interfere with reproduction and hence are not desirous for women desiring immediate fertility. Mifepristone has been shown to have a significant beneficial effect on symptoms and extent of disease with administration of disease, $50 \mathrm{mg}$ daily for 6 months [107]. The rationale for the use of asoprisnil in the management of endometriosis is based on the presumed effect of tissue selective inhibition of endometrial proliferation and suppression of endometrial bleeding by targeting endometrial vasculature directly [105] [108]. The finding of tissue specific suppression of endometrial production and preclinical studies also appeared to be promising with regard to the potential of asoprisnil to ameliorate endometriosis associated pain [105] [109]. Phase II studies with asoprisnil have been conducted in women with pelvic pain due to endometriosis. In a randomized study doses of 5, 10, $25 \mathrm{mg}$ asoprisnil were administered for 12 weeks to women with a laparoscopic diagnosis of endometriosis who suffered moderate to severe pain. All three doses significantly reduced nonresponsive pelvic pain and dysmenorrhea compared to placebo [105]. They had a favourable safetyand tolerability profile during the 3month period. Nolaboratory or clinical evidence of estrogen deprivation was found. Only 2 of the SPRM's are currently approved for gynaecologic use. Mifepristone, for the termination of pregnancy, cervical dilatation, MTP during the second trimester and fetal death in utero [110] [111]. Ulipristal Acetate has been approved in europe, united states as an emergency contraceptive and recently European commission approved it for preoperative treatment of fibroids [112] [113]. Common side effects are headache, abdominal pain and tenderness. Endometrial changes known as progesterone receptor mediated endometrial changes are induced which have been found to be reversible. BMD is not affected, estrogen levels are not affected. Still more RCT's need to be developed to assess potential efficacy in endometriosis associated pain, but seems to be promising for nonresponsive pain.

\section{Antiinflammatory Agents}

\subsection{Cyclooxygenase Inhibitors (COX I)}

Prostaglandin synthesis requires COX1 and COX2. Overexpression of COX2 has been detected in eutopic endometrium from patients with endometriosis as compared to controls, whose expression is known to be increased in inflammation and angiogenic processes [114]. In vitro celecoxib (COX2 inhibitor) inhibited cell proliferation and induced apoptosis in cultures of endometrial epithelial and stromal cells. PGE2 and VEGF re- 
leased by these cells were also significantly reduced. In vivo celecoxib statistically significantly reduced the number and size of peritoneal endometriosis-like lesions in mice, when administered before/after induction of lesions [115]-[117]. Astudy in mice compared the response of endometriotic lesions to celecoxib, anastrazole or their combination [118]. Celecoxib was the only treatment that significantly reduced the number of lesions established/mouse, lesion size and vascularized area. Cell proliferation was significantly diminished and apoptosis was significantly enhanced by both individual treatments on combining the therapies their effects were reversed. This confirms on their own both celecoxib and anastrazole individually decrease endometriotic growth but on combining have an antagonistic effect.

Arandomized double blind placebo controlled study was carried out in 28 women using $25 \mathrm{mg}$ of rolecoxib a day $\times 6$ months [119]. The results showed more effective control of pain in the relecoxib group than in placebo group with no significant side effects. The results of in vitro studies though show that from above results COX2 inhibitors are ideal options for treatment of endometriosis associated pain, relecoxib and valdecoxib have been withdrawn from the market because of severe CVS side effects in long term users [120]. Currently thus not enough evidence and no clinical trials to recommend them for endometriosis associated short term pain relief.

\subsection{Peroxisome Proliferator-Activated Receptor- $\gamma$ Agonists}

PPAR $\gamma$ ligands modulate cell growth and angiogenesis likely because of downregulation of growth and angiogenesis, because of downregulation of proinflammatory mediators in macrophages [121]. They also inhibit E2 production by inhibiting aromatase cytochrome P450 [122]. Thiazolidinediones, are a class of compounds with high affinity for PPAR $\gamma$, consisting of pioglitazone, ciglitazone and rosiglitazone. Culture of Hesc's or stromal/ fibloblast like cells like lines exposed to these drugs display reduced TNF $\alpha$ induced IL-8 secretion and statistically significant inhibition of cell proliferation in a dose dependent manner [123] [124]. Rosiglitazone and ciglitazone were able to reduce the weight and volume of lesions in murine model of endometriosis as compared to controls [117] [125]-[127]. With rosiglitazone cell proliferation as well vascularization was inhibited, along with increased apoptosis [117] [126] [127]. The potential negative effects were not assessed on reproductive function, but no evidence of interference with estrus cycle/folliculogenesis has been reported with ciglitazone [126]. Pioglitazone was used in the treatment of induced endometriosis in baboons. The endometrial tissue to be implanted in animals had to be previously incubated in a solution with this molecule. Volume and surface area of endometriosis like lesions, with specially the number and surface area of red lesions were statistically significantly lower in pioglitazone treated baboons as compared to controls [128]. Rosiglitazone, in same model, produced a statistically significant reduction in the surface area of lesions, with no interference with mean P levels [121]. Fenfibrate, a PPAR $\alpha$ ligand also reduces mean number of implants in a rat endometriotic model [129].

\subsection{Telmesartan}

Telmesartan is a partial agonist of PPAR $\gamma$ with antiatherogenic properties which, in contrast to full agonists additionally block Angiotensin 1 receptor (AT1R). Hence, telmesartan is widely used for the treatment of hypertensive patients. Of interest AT1R is also expressed in endometrial stromal cells [130]. Moreover AT1R activation induces VEGF driven angiogenesis [131] and stimulates inflammation via increased expression of leukocytes and endothelial adhesion molecules [132]. Accordingly it has been reported that the AT1 Rantagonist action of telemesartan inhibits choroidal inflammation and neovascularization [133] and prevent hepato carcinogenesis by suppressing hepatic blood vessels formation [134]. Based on these findings the group of Laschke et al. speculated that telmesartan maybe more effectivein treatment of endometriosis than PPAR $\gamma$ agonists by combining AT1R blockade and PPAR gamma activation. Hence to test their hypothesis they analysed the antiangiogenic action of telmsartan in comparison to full PPAR gamma pioglitazone by means of an aortic ring assay. They further studied the effects of both compounds on vascularisation, immune cell content and growth of endometriosis like lesions in dorsal skin chamber and a peritoneal model of endometriosis. They found telmesartan inhibited vascular sprout formation of aortic rings more effectively than pioglitazine. Thus in dorsal skin chamber lower vascular density of blood vessels and blood perfusion was found in telmesartan vs pioglitazone group. Temisartan also inhibited the stromal tissue growth resulting in significantly reduced final lesion volume as assessed by high resolution ultrasound. Further Telmesartan induced an upregulation of PPAR gamma and a downregulation of AT1R proteins in endometriotic lesions, which was associated with decreased density of CD31 positive microvessels, a reduced number of immune cell content, and a lower number of Ki67, positive 
proliferating cells. qtPCR further demonstrated inhibitory action on expression of several angiogenic genes and inflammatory genes by telmesartaan. Thus, they concluded that telmisartan inhibits vascularzation, immune cell content and growth of endometriotic like lesions. The combined blockade of AT1R and PPAR gamma represents a promising new concept in the development of novel compounds for endometriosis treatment [135].

\section{Immunomodulators}

Immunomodulatory agents have been suggested for the treatment of endometriosis. In line with the fact that there is a close link between inflammation and angiogenesis [136], some of these agents have been described to exert specific antiangiogenic effect on endometriotic lesions, These include lipoxin A4(LXA4,], rapamycin [lashcke006b], pentoxyphylline.

LXA4 is endogenous eicasanoid which is induced in the regulation of various inflammatory processes [137]. In vivo and vitro it has been shown to inhibit VEGF stimulated endothelial proliferation and angiogenesis [138] [139]. Both in rats as well as experimental endometriosis from patients with endometriosis a higher LXA4 receptor was found than controls. Hence, $\mathrm{Xu}$ et al. recently analyzed the effects of LXA4on angiogenesis in mouse. They found that treatment with LXA4 inhibits activity of MMP9and decreases mRNA levels of VEGF in endometriotic lesions resulting in significant growth suppression and atrophy of the glands. However the treatment does not alter the serum E2 and Pg levels of diestrus-estrus cycles [140].

Rapamycin is a mammalian target of rapamycy in inhibitor, which is widely used in immunosuppressive doses to inhibit tumor angiogenesis by decreasing VEGF production [141]. Based on these results the effects of rapamycin on endometriosis lesions was analysed in the dorsal skin chamber model [49]. Daily treatment of the lesions with $1.5 \mathrm{~kg} / \mathrm{kg}$ Rapamycin induced their regression which was associated with an inhibition of VEGF mediated angiogenesis. In addition, rapamycin suppressed he proliferation of endometrial and endothelial cell. Thus although rapamycn also represents an effective inhibitor of angiogenesis in ectopic endometrial tissue ,its immunosuppressive effect and risk profile, make it questionable whether it will ever make it easy into clinical efficacious therapy.

Immunomodulatory agents like pentoxyphylline have been suggested for the treatment of endometriosis [142], is well tolerated and does not inhibit ovulation [143]. Some clinical trials have been published comparing using pentoxyphylline vs placebo after conservative surgery [144]-[147] but there was no evidence of an increase in clinical pregnancy or improvement in pain scores. No adverse events were reported. In a recent Cochrane review, it was concluded that, there is little evidence which supports pentoxifylline use for subferility in women with endometriosis at this time [148].

Sorafenib is a strong multikinase inhibitor targeting two different pathways of endometriosis pathogenesis RAF Kinase and VEGFR. Leconte et al. studied stromal primary cells extracted from 10 endometriosis patients with and without endometriosis. Treating endometriotic cells with sorafenib abrogated phosphorylation of extracellular signal related kinase in stromal cells of women with endometriosis as compared to controls. In addition sorafenib had antiangiogenic effects as demonstrated by a decreased phosphorylated VEGF2-VEGFR2 ratio in endometriosis. They confirmed that sorafenib regulated endometriosis in vivo by targeting endometriosis related inflammation by using a xenogenic mouse model. Thus confirming sorafenib controls growth of endometriotic levels both in vivo as well as in vitro [149].

\section{Discussion}

- Thus in a nutshell, endometriosis is a benign disease with marked similarities to autoimmune disease belonging to a group of angiogenic diseases like rheumatoid arthritis, psoariasis, diabetic retinopathy, tumour growth and metastasis. The major survival factor is angiogenesis.

- Pain can be secondary to inflammatory reaction, pelvic nerves as well as invasion along pain transmitting nerves going together into endometriotic lesions known as neuroangiogenesis.

- Of the growth factor inhibitors VEGF antibody like bevaczumab have demonstrated antiendometriotic activity but have limited applications because of severe side effects.

- Although mice having increased expression of VEGF treated for 2 months 2methoxy estradiol—an antiangiogenic agent dose dependently suppresses lesions at higher doses yet its pharmacokinetic properties still need to be resolved before clinical use can be considered.

- Combined inhibition of all of 3 growth factors like VEGF, bFGF, PDGF is much more effective in suppress- 
ing lesional vascularisation, than blockade of VEGF alone.

- Rasveratrol, a phytotherapeutic agent, hold promise in decreasing angiogenesis in endometriosis along with cell proliferation although clinical human testing is awaited.

- Although studies on statins like atorvastatin have demonstrated more effective in suppressing endometriotic lesional vascularisation than blockade of VEGF alone, antiangiogenic activity in endometriotic lesions without affecting reproductive function, the special review by Vitagilano still rules out their use in endometriosis because of uncertainties in gonadal function.

- Dopamine agonists like cabergoline although effective suffered from side effects like cardiac valve regurgitation. Hence, nonergot derived dopamine agonist quinagolide had been compared with cabergoline In a pilot study and both found to be equally effective .Still larger clinical trials are warranted although quinagolide is a drug for future treatment.

- TNF $\alpha$ inhibitors-Although TNF- $\alpha$ is an inflammatory cytokine having a role in pathophysiology of endometriosis inflimixab (a monoclonal antibody) nether improved pain scores in rectovagnal endometriosis and was associated with severe side effects.

- Elagolix-A GnRH antagonist significantly suppresses dysmenorrhea, dyspareunia during first week of treatment and has acceptable safety profile. BMD was much lower than Gn RH agonist leuprolide. Still additional studies are warranted to use it as routine drug for endometriosis associated pain.

- COX2 inhibitors-In mice celecoxib and anastrazole in comintion had a $\mathrm{n}$ antagonistic role although by itself both reduced individually endometriosis lesions but having antagonistic action on combination. Although rolecoxib $25 \mathrm{mg}$ showed marked relief in endometriosis associated pain recently both rolecoxib and valdecoxib have been withdrawn because of sever CVS side effects.

- PPAR- $\gamma$ agonists-Pioglitazone found effective in treating endometriosis induced in baboons, with these ligands downregulating growth and angiogenesis by downregulation of macrophages., as well as inhibiting E2production by inhibiting aromatase cytochtome P450.

- Telmesartan-Partial agonist of PPAR $\gamma$ with antiatherogenic properties along with angiotensin 1 receptor (AT1R) blocker-in animal studies upregulated PPAR gamma while downregulating AT1Rproteins inendometriotic lesions, associared with decreased CD31positive microvessel reduced number and holds promise as a new treatment with currently being used in humans as an antihypertensive drug.

- SPRM - Although asoprisnil and mifepristone have shown some promise inreducing endometriosis, their current use is limited because of effects on fertility and secondly only Mifepristone and ulipristal are two drugs currently approved by FDA for two different indications like fibroids, MTP.

- Immunomodulators like lipoxin A4, Rapamycin suggested although pentoxyphylline is the one most studied. But despite that little evidence on cochrane review for support of pentoxyphylline in women with subferility with endometriosis.

\section{Conclusion}

At present, the hormonal treatments including hormonal oral contraceptives, transdermal, vaginal administration, medroxyprogesterone acetate-either oral or depot, dienogest, cyproteroneacetate, norethindrone acetate, danazol, levonorgestrel containing IUCD, antiprogestins like gestrinone and Gn RH agonists remain the drugs of choice primarily but not without their drawbacks. Among nonhormonal drugs, the only ones approved for pain associated with endometriosis which is aromatase inhibitor. Increasing number of randomized trials are needed to develop SPRM's with efficiency as well as long term safety. New nonhormonal agents need to be developed that do not block ovaries. Although statins seemed to offer this advantage, this has been questioned by Vitiligano. Similarly, developing newer antiangiogenic drugs is needed and resveratrol may be a potential candidate although human RCT's is required. Recently, roles of retinoids and inflammation pathway have been questioned for the pathophysiology of endometriosis and development of low side effect profile retinoid supplementation might provide a new treatment option for long term management of the chronic disabilitating diseases as an adjuvant therapy [150]. GnRH antagonists are still under phase III controlled trial although they seem to be efficacious for short term therapy for pain without considerable side effects as associated with GnRH agonists.

\section{References}

[1] Galle, P.C. (1989) Clinical Presentation and Diagnosis of Endometriosis. Obstetrics and Gynecology Clinics of North 
America, 16, 29-42.

[2] Simmons, S., Hummelshog, L. and D’Hooge, T. (2007) Endometriosis: Cost Estimates and Methodological Perspective. Human Reproduction Update, 13, 395-344. http://dx.doi.org/10.1093/humupd/dmm010

[3] Stratton, P. and Berksley, K.J. (2011) Chronic Pelvic Pain and Endometriosis: Translational Evidence of the Relationship and Implications. Human Reproduction Update, 17, 327-348. http://dx.doi.org/10.1093/humupd/dmq050

[4] Garrido, N., Navarro, J., García-Velasco, J., Remohí, J., Pellicer, A. and Simón, C. (2002) The Endometrium versus Embryonic Quality in Endometriosis-Related Infertility. Human Reproduction Update, 8, 95-100.

http://dx.doi.org/10.1093/humupd/8.1.95

[5] Bulleti, C., Coccia, M.E., Baltistani, S. and Borini, A. (2010) Endometriosis and Infertility. Journal of Assisted Reproduction and Genetics, 27, 441-447.

[6] Gilmour, J.A., Huntington, A. and Wilson, H.V. (2008) The Impact of Endometriosis on Work and Social Participation. International Journal of Nursing Practice, 14, 443-448. http://dx.doi.org/10.1111/j.1440-172X.2008.00718.x

[7] Donnez, J., Nisolle, M., Casanas-Roux, F., Bassil, S. and Anaf, V. (1995) Rectovaginal Septum, Endometriosis or Adenomyosis: Laparoscopic Management in a Series of 231 Patients. Human Reproduction, 10, 630-635.

[8] Nisolle, M. and Donnez, J. (1997) Peritoneal Endometriosis, Ovarian Endometriosis, and Adenomyotic Nodules of the Rectovaginal Septum Are Three Different Entities. Fertility and Sterility, 68, 585-596. http://dx.doi.org/10.1016/S0015-0282(97)00191-X

[9] Tokushige, N., Markham, R., Russell, P. and Fraser, I.S. (2006) Nerve Fibres in Peritoneal Endometriosis. Human Reproduction, 21, 3001-3007. http://dx.doi.org/10.1093/humrep/del260

[10] McKinnon, B., Bersinger, N.A., Wotzkow, C. and Mueller, M.D. (2012) Endometriosis-Associated Nerve Fibers, Peritoneal Fluid Cytokine Concentrations, and Pain in Endometriotic Lesions from Different Locations. Fertility and Sterility, 97, 373-380. http://dx.doi.org/10.1016/j.fertnstert.2011.11.011

[11] Johnson, N.P., Hummelshoj, L., for the World Endometriosis Society Montpellier Consortium (2013) Consensus on Current Management of Endometriosis. Human Reproduction, 28, 1552-1568. http://dx.doi.org/10.1093/humrep/det050

[12] Streuli, I., de Ziegler, D., Santulli, P., et al. (2013) An Update on the Pharmacological Management of Endometriosis. Expert Opinion on Pharmacotherapy, 14, 291-305. http://dx.doi.org/10.1517/14656566.2013.767334

[13] Allen, C., Hopewell, S., Prentice, A. and Gregory, D. (2009) Nonsteroidal Antiinflammatory Drugs for Pain in Women with Endometriosis. Cochrane Database of Systematic Reviews, 2, CD004753.

[14] Sampson, J.A. (1927) Peritoneal Endometriosis Due to the Menstrual Dissemination of Endometrial Tissue into the Peritoneal Cavity. American Journal of Obstetrics \& Gynecology, 14, 442-469. http://dx.doi.org/10.1016/S0002-9378(15)30003-X

[15] Bulun, S.E. (2009) Endometriosis. The New England Journal of Medicine, 360, 268-279. http://dx.doi.org/10.1056/NEJMra0804690

[16] Santulli, P., Marcellin, L., Noël, J.C., Borghese, B., Fayt, I., Vaiman, D., Chapron, C. and Méhats, C. (2012) Sphingosine Pathway Deregulation in Endometriotic Tissues. Fertility and Sterility, 97, 904-911. http://dx.doi.org/10.1016/j.fertnstert.2011.12.051

[17] González-Ramos, R., Van Langendonckt, A., Defrère, S., Lousse, J.C., Colette, S., Devoto, L. and Donnez, J. (2010) Involvement of the Nuclear Factor- $\kappa$ B Pathway in the Pathogenesis of Endometriosis. Fertility and Sterility, 94, 19851994. http://dx.doi.org/10.1016/j.fertnstert.2010.01.013

[18] Yagyu, T., Kobayashi, H., Matsuzaki, H., et al. (2005) Thalidomide Inhibits Tumor Necrosis Factor- $\alpha$-Induced Interleukin-8 Expression in Endometriotic Stromal Cells, Possibly through Suppression of Nuclear Factor- $\kappa$ B Activation. The Journal of Clinical Endocrinology \& Metabolism, 90, 3017-3021. http://dx.doi.org/10.1210/jc.2004-1946

[19] Huber, A.V., Saleh, L., Prast, J., Haslinger, P. and Knöfler, M. (2007) Human Chorionic Gonadotrophin Attenuates NF- $\kappa$ B Activation and Cytokine Expression of Endometriotic Stromal Cells. Molecular Human Reproduction, 13, 595604. http://dx.doi.org/10.1093/molehr/gam032

[20] Grund, E.M., Kagan, D., Tran, C.A., Zeitvogel, A., Starzinski-Powitz, A., Nataraja, S. and Palmer, S.S. (2008) Tumor Necrosis Factor- $\alpha$ Regulates Inflammatory and Mesenchymal Responses via Mitogen-Activated Protein Kinase Kinase, p38, and Nuclear Factor $\kappa$ B in Human Endometriotic Epithelial Cells. Molecular Pharmacology, 73, 1393-1404. http://dx.doi.org/10.1124/mol.107.042176

[21] Zhang, J.-J., Xu, Z.-M., Dai, H.-Y., Ji, X.-Q., Duan, Y.-Y., Zhang, C.-M. and Qin, D.-Y. (2010) Application of the Nuclear Factor- $\kappa$ B Inhibitor Pyrrolidine Dithiocarbamate for the Treatment of Endometriosis: An in Vitro Study. Fertility and Sterility, 94, 2942-2944. http://dx.doi.org/10.1016/j.fertnstert.2010.05.009

[22] Soares, S.R., Martínez-Varea, A., Hidalgo-Mora, J.J. and Pellicer, A. (2012) Pharmacologic Therapies in Endometri- 
osis: A Systematic Review. Fertility and Sterility, 98, 529-555. http://dx.doi.org/10.1016/j.fertnstert.2012.07.1120

[23] Barrier, B.F. (2010) Immunology of Endometriosis. Clinical Obstetrics \& Gynecology, 53, 397-402. http://dx.doi.org/10.1097/GRF.0b013e3181db7c33

[24] Mathur, S.P. (2000) Autoimmunity in Endometriosis: Relevance to Infertility. American Journal of Reproductive Immunology, 44, 89-95. http://dx.doi.org/10.1111/j.8755-8920.2000.440204.x

[25] De Ziegler, D., Borghese, B. and Chapron, C. (2010) Endometriosis and Infertility: Pathophysiology and Management. The Lancet, 376, 730-738. http://dx.doi.org/10.1016/S0140-6736(10)60490-4

[26] Slabe, N., Meden-Vrtovec, H., Verdenik, I., Kosir-Pogacnik, R. and Ihan, A. (2013) Cytotoxic T-Cells in Peripheral Blood in Women with Endometriosis. Geburtshilfe Frauenheilkd, 73, 1042-1048. http://dx.doi.org/10.1055/s-0033-1350702

[27] May, K.E., Conduit-Hulbert, S.A., Villar, J., et al. (2010) Peripheral Biomarkers of Endometriosis: A Systematic Review. Human Reproduction Update, 16, 651-674. http://dx.doi.org/10.1093/humupd/dmq009

[28] Khoufache, K., Michaud, N., Harir, N., Kibangou Bondza, P. and Akoum, A. (2012) Anomalies in the Inflammatory Response in Endometriosis and Possible Consequences: A Review. Minerva Endocrinologica, 37, 75-92.

[29] Alay, Z., Saed, G.M. and Diamond, M.P. (2006) Female Infertility and Free Radicals: Potential Role in Adhesion Adhesions and Endometriosis. Reproductive Sciences, 13, 390-398. http://dx.doi.org/10.1016/j.jsgi.2006.05.002

[30] Gargett, C.E. and Masuda, H. (2010) Adult Stem Cells in the Endometrium. Molecular Human Reproduction, 16, 818834. http://dx.doi.org/10.1093/molehr/gaq061

[31] Figueira, P.G., Abrão, M.S., Krikun, G. and Taylor, H. (2011) Stem Cells in Endometrium and Their Role in the Pathogenesis of Endometriosis. Annals of the New York Academy of Sciences, 1221, 10-17. http://dx.doi.org/10.1111/j.1749-6632.2011.05969.x

[32] Nisolle, M., Casanas-Roux, F., Anaf, V., Mine, J.M. and Donnez, J. (1993) Morphometric Study of the Stromal Vascularization in Peritoneal Endometriosis. Fertility and Sterility, 59, 681-684. http://dx.doi.org/10.1016/S0015-0282(16)55823-3

[33] McLaren, J. (2000) Vascular Endothelial Growth Factor and Endometriotic Angiogenesis. Human Reproduction Update, 6, 45-55. http://dx.doi.org/10.1093/humupd/6.1.45

[34] Laschke, M.W. and Menger, M.D. (2007) In Vitro and in Vivo Approaches to Study Angiogenesis in the Pathophysiology and Therapy of Endometriosis. Human Reproduction Update, 13, 331-342. http://dx.doi.org/10.1093/humupd/dmm006

[35] Healy, D.L., Rogers, P.A.W., Hii, L. and Wingfield, M. (1998) Angiogenesis: A New Theory for Endometriosis. Human Reproduction Update, 4, 736-740. http://dx.doi.org/10.1093/humupd/4.5.736

[36] Laschke, M.W., Elitzsch, A., Vollmar, B., Vajkoczy, P. and Menger, M.D. (2006) Combined Inhibition of Vascular Endothelial Growth Factor (VEGF), Fibroblast Growth Factor and Platelet-Derived Growth Factor, but Not Inhibition of VEGF Alone, Effectively Suppresses Angiogenesis and Vessel Maturation in Endometriotic Lesions. Human Reproduction, 21, 262-268. http://dx.doi.org/10.1093/humrep/dei308

[37] Feng, D., Welker, S., Körbel, C., et al. (2012) Protein Kinase CK2 Is a Regulator of Angiogenesis in Endometriotic Lesions. Angiogenesis, 15, 243-252. http://dx.doi.org/10.1007/s10456-012-9256-2

[38] Laschke, M.W. and Menger, M.D. (2012) Anti-Angiogenic Treatment Strategies for the Therapy of Endometriosis. Human Reproduction Update, 18, 682-702. http://dx.doi.org/10.1093/humupd/dms026

[39] Anaf, V., Simon, P., El Nakadi, I., et al. (2002) Hyperalgesia, Nerve Infiltration and Nerve Growth Factor Expression in Deep Adenomyotic Nodules, Peritoneal and Ovarian Endometriosis. Human Reproduction, 17, 1895-1900. http://dx.doi.org/10.1093/humrep/17.7.1895

[40] Alvarez, P., Chen, X., Hendrich, J., et al. (2012) Ectopic Uterine Tissue as a Chronic Pain Generator. Neuroscience, 225, 269-282. http://dx.doi.org/10.1016/j.neuroscience.2012.08.033

[41] Asante, A. and Taylor, R.N. (2011) Endometriosis: The Role of Neuroangiogenesis. Annual Review of Physiology, 73, 161-182. http://dx.doi.org/10.1146/annurev-physiol-012110-142158

[42] Novella-Maestre, E., Herraiz, S., Vila-Vives, J.M., Carda, C., Ruiz-Sauri, A. and Pellicer, A. (2012) Effect of Antiangiogenic Treatment on Peritoneal Endometriosis-Associated Nerve Fibers. Fertility and Sterility, 98, 1209-1217. http://dx.doi.org/10.1016/j.fertnstert.2012.07.1103

[43] Ahn, S.H., Edwards, A.K., Singh, S.S., Young, S.L., Lessey, B.A. and Tayade, C. (2015) IL-17A Contributes to the Pathogenesis of Endometriosis by Triggering Proinflammatory Cytokines and Angiogenic Growth Factors. The Journal of Immunology, 195, 2591-2600. http://dx.doi.org/10.4049/jimmunol.1501138

[44] Zhang, J.-J., Xu, Z.-M., Zhang, C.-M., Dai, H.-Y., Ji, X.-Q., Wang, X.-F. and Li, C. (2011) Pyrrolidine Dithiocarba- 
mate Inhibits Nuclear Factor- $\kappa$ B Pathway Activation, and Regulates Adhesion, Migration, Invasion and Apoptosis of Endometriotic Stromal Cells. Molecular Human Reproduction, 17, 175-181. http://dx.doi.org/10.1093/molehr/gaq090

[45] Zhang, H., Li, M.J., Wang, F.L., Liu, S., Li, J.J., Wen, Z.Q. and Zhao, X.B. (2010) Endometriotic Epithelial Cells Induce MMPs Expression in Endometrial Stromal Cells via an NF $\kappa$ B-Dependent Pathway. Gynecological Endocrinology, 26, 456-467. http://dx.doi.org/10.3109/09513590903366988

[46] Nasu, K., Nishida, M., Ueda, T., Yuga, M., Takai, N. and Narahara, H. (2007) Application of the Nuclear Factor- $\kappa$ B Inhibitor BAY 11-7085 for the Treatment of Endometriosis: An in Vitro Study. American Journal of Physiology-Endocrinology and Metabolism, 293, E16-E23. http://dx.doi.org/10.1152/ajpendo.00135.2006

[47] Kim, J.-H., Yang, Y.-I., Lee, K.-T., Park, H.-J. and Choi, J.-H. (2011) Costunolide Induces Apoptosis in Human Endometriotic Cells through Inhibition of the Prosurvival Akt and Nuclear Factor Kappa B Signaling Pathway. Biological and Pharmaceutical Bulletin, 34, 580-585. http://dx.doi.org/10.1248/bpb.34.580

[48] Giudice, L.C. and Kao, L.C. (2004) Endometriosis. The Lancet, 364, 1789-1799. http://dx.doi.org/10.1016/S0140-6736(04)17403-5

[49] Nothnick, W.B. (2010) Endometriosis: In Search of Optimal Treatment. Minerva Ginecologica, 62, 17-31.

[50] Pullen, N., Birch, C.L., Douglas, G.J., Hussain, Q., Pruimboom-Brees, I. and Walley, R.J. (2013) The Translational Challenge in the Development of New and Effective Therapies for Endometriosis: A Review of Confidence from Published Preclinical Efficacy Studies. Human Reproduction Update, 17, 791-802. http://dx.doi.org/10.1093/humupd/dmr030

[51] Laschke, M.W., Giebels, C., Nickels, L.M., Scheueur, C. and Menger, M.D. (2011) Endometrial Progenitor Cells Contribute to the Vascularization of Endometriotic Lesions. The American Journal of Pathology, 178, 442-450. http://dx.doi.org/10.1016/j.ajpath.2010.11.037

[52] Chung, H.W., Wen, Y., Choi, E.A., Li, H., Moon, H.S., Yu, H.K. and Polan, M.L. (2002) Pleiotrophin (PTN) and Midkine (MK) mRNA Expression in Eutopic and Ectopic Endometrium in Advanced Stage Endometriosis. Molecular Human Reproduction, 8, 350-355. http://dx.doi.org/10.1093/molehr/8.4.350

[53] Donnez, J., Smoes, P., Gillerot, S., Casanas-Roux, F. and Nisolle, H. (1998) Vascular Endothelial Growth Factor (VEGF) in Endometriosis. Human Reproduction, 13, 1686-1690. http://dx.doi.org/10.1093/humrep/13.6.1686

[54] Sharkey, A.M., Day, K., McPherson, A., Malik, S., Licence, D., Smith, S.K. and Charnock-Jones, D.S. (2000) Vascular Endothelial Growth Factor Expression in Human Endometrium Is Regulated by Hypoxia. The Journal of Clinical Endocrinology \& Metabolism, 85, 402-409.

[55] Hull, M.L., Charnock-Jones, D.S., Chan, C.L., Bruner-Tran, K.L., Osteen, K.G., Tom, B.D., Fan, T.P. and Smith, S.K. (2003) Antiangiogenic Agents Are Effective Inhibitors of Endometriosis. The Journal of Clinical Endocrinology \& Metabolism, 88, 2889-2899. http://dx.doi.org/10.1210/jc.2002-021912

[56] Nap, A.W., Griffioen, A.W., Dunselman, G.A., et al. (2004) Antiangiogenesis Therapy for Endometriosis. The Journal of Clinical Endocrinology \& Metabolism, 89, 1089-1095. http://dx.doi.org/10.1210/jc.2003-031406

[57] Nap, A.W., Dunselman, G.A.J., Griffioen, A.W., Mayo, K.H., Evers, J.L.H. and Groothuis, P.G. (2005) Angiostatic Agents Prevent the Development of Endometriosis-Like Lesions in the Chicken Chorioallantoic Membrane. Fertility and Sterility, 83, 793-795. http://dx.doi.org/10.1016/j.fertnstert.2004.06.080

[58] Kamba, T. and McDonald, D.M. (2007) Mechanisms of Adverse Effects of Anti-VEGF Therapy for Cancer. British Journal of Cancer, 96, 1788-1795. http://dx.doi.org/10.1038/sj.bjc.6603813

[59] Shweiki, D., Itin, A., Soffer, D. and Keshet, E. (1992) Vascular Endothelial Growth Factor Induced by Hypoxia May Mediate Hypoxia-Initiated Angiogenesis. Nature, 359, 843-845. http://dx.doi.org/10.1038/359843a0

[60] Harris, A.E. (2002) Hypoxia-A Key Regulatory Factor in Tumour Growth. Nature Reviews Cancer, 2, 38-47. http://dx.doi.org/10.1038/nrc704

[61] Becker, C.M., Rohwer, N., Funakoshi, T., Cramer, T., Bernhardt, W., Birsner, A., Folkman, J. and D’Amato, R.J. (2008) 2-Methoxyestradiol Inhibits Hypoxia-Inducible Factor-1 $\alpha$ and Suppresses Growth of Lesions in a Mouse Model of Endometriosis. The American Journal of Pathology, 172, 534-544. http://dx.doi.org/10.2353/ajpath.2008.061244

[62] Kulke, M.H., Chan, J.A., Meyerhardt, J.A., et al. (2011) A Prospective Phase II Study of 2-Methoxyestradiol Administered in Combination with Bevacizumab in Patients with Metastatic Carcinoid Tumors. Cancer Chemotherapy and Pharmacology, 68, 293-300. http://dx.doi.org/10.1007/s00280-010-1478-7

[63] Dahut, W.L., Lakhani, N.J., Gulley, J.L., et al. (2006) Phase I Clinical Trial of Oral 2-Methoxyestradiol, an Antiangiogenic and Apoptotic Agent, in Patients with Solid Tumors. Cancer Biology \& Therapy, 5, 22-27. http://dx.doi.org/10.4161/cbt.5.1.2349

[64] Verenich, S. and Gerk, P.M. (2010) Therapeutic Progress of 2-Methoxyestradiol and Its Drug Deposition Challenges. Molecular Pharmaceutics, 7, 2030-2039. http://dx.doi.org/10.1021/mp100190f 
[65] Mendel, D.B., Laird, A.D., Smolich, et al. (2000) Development of SU5416, a Selective Small Molecule Inhibitor of VEGF Receptor Tyrosine Kinase Activity, as an Anti-Angiogenesis Agent. Anti-Cancer Drugs Design, 15, 29-41.

[66] Laschke, M.W., Elitzsch, A., Scheuer, C., Holstein, J.H., Vollmar, B. and Menger, M.D. (2006) Rapamycin Induces Regression of Endometriotic Lesions by Inhibiting Neovascularization and Cell Proliferation. British Journal of Pharmacology, 149, 137-144. http://dx.doi.org/10.1038/sj.bjp.0706857

[67] Donaghay, M. and Lessey, B.A. (2007) Uterine Receptivity: Alterations Associated with Benign Gynecological Disease. Seminars in Reproductive Medicine, 25, 461-475. http://dx.doi.org/10.1055/s-2007-991044

[68] Wei, Q., St Clair, J.B., Fu, T., Stratton, P. and Nieman, L.K. (2008) Reduced Expression of Biomarkers Associated with the Implantation Window in Women with Endometriosis. Fertility and Sterility, 91, 1686-1691. http://dx.doi.org/10.1016/j.fertnstert.2008.02.121

[69] Tiberi, F., Tropea, A., Apa, R., Romani, F., Lanzone, A. and Marana, R. (2010) Prokineticin 1 mRNA Expression in the Endometrium of Healthy Women and in the Eutopic Endometrium of Women with Endometriosis. Fertility and Sterility, 93, 2145-2149. http://dx.doi.org/10.1016/j.fertnstert.2009.01.105

[70] Lu, Z., Hardt, J. and Kim, J.J. (2008) Global Analysis of Genes Regulated by HOXA10 in Decidualization Reveals a Role in Cell Proliferation. Molecular Human Reproduction, 14, 357-366. http://dx.doi.org/10.1093/molehr/gan023

[71] Krumlauf, R (1994) Hox Genes in Vertebrate Development. Cell, 78, 191-201. http://dx.doi.org/10.1016/0092-8674(94)90290-9

[72] McGinnis, W. and Krumlauf, R. (1992) Homeobox Genes and Axial Patterning. Cell, 68, 283-302. http://dx.doi.org/10.1016/0092-8674(92)90471-N

[73] Tiberi, F., Tropea, A., Romani, F., Apa, R., Marana, R. and Lanzone, A. (2010) Prokineticin 1, Homeobox A10, and Progesterone Receptor Messenger Ribonucleic Acid Expression in Primary Cultures of Endometrial Stromal Cells Isolated from Endometrium of Healthy Women and from Eutopic Endometrium of Women with Endometriosis. Fertility and Sterility, 94, 2558-2563. http://dx.doi.org/10.1016/j.fertnstert.2010.03.006

[74] Lee, K.-F., Lee, Y.-L., Chan, R.W.S., Cheong, A.W.Y., Ng, E.H.Y., Ho, P.-C. and Yeung, W.S.B. (2010) Up-Regulation of Endocrine Gland-Derived Vascular Endothelial Growth Factor but Not Vascular Endothelial Growth Factor in Human Ectopic Endometriotic Tissue. Fertility and Sterility, 93, 1052-1060. http://dx.doi.org/10.1016/j.fertnstert.2008.12.001

[75] Chen, Y. and Tseng, S.H. (2007) Review. Pro- and Anti-Angiogenesis Effects of Resveratrol. In Vivo, 21, 365-370.

[76] Cao, Z.X., Fang, J., Xia, C., Shi, X.L. and Jiang, B.-H. (2004) trans-3,4,5'-Trihydroxystibene Inhibits Hypoxia-Inducible Factor $1 \alpha$ and Vascular Endothelial Growth Factor Expression in Human Ovarian Cancer Cells. Clinical Cancer Research, 10, 5253-5263. http://dx.doi.org/10.1158/1078-0432.CCR-03-0588

[77] Zhang, Q., Tang, X., Lu, Q.Y., Zhang, Z.F., Brown, J. and Li, A.D. (2005) Resveratrol Inhibits Hypoxia-Induced Accumulation of Hypoxia-Inducible Factor-1 $\alpha$ and VEGF Expression in Human Tongue Squamous Cell Carcinoma and Hepatoma Cells. Molecular Cancer Therapeutics, 4, 1465-1474. http://dx.doi.org/10.1158/1535-7163.MCT-05-0198

[78] Ganapathy, S., Chen, Q.H., Singh, K.P., Shankar, S. and Srivastava, R.K. (2010) Resveratrol Enhances Antitumor Activity of TRAIL in Prostate Cancer Xenografts through Activation of FOXO Transcription Factor. PLoS ONE, 5, e15627. http://dx.doi.org/10.1371/journal.pone.0015627

[79] Kaneko, H., Anzai, T., Morisawa, M., et al. (2011) Resveratrol Prevents the Development of Abdominal Aortic Aneurysm through Attenuation of Inflammation, Oxidative Stress, and Neovascularization. Atherosclerosis, 217, 350-357. http://dx.doi.org/10.1016/j.atherosclerosis.2011.03.042

[80] Carmeliet, P. (2000) Mechanisms of Angiogenesis and Arteriogenesis. Nature Medicine, 6, 389-395.

[81] Hu, Y., Sun, C.Y., Huang, J., Hong, L., Zhang, L. and Chu, Z.B. (2007) Antimyeloma Effects of Resveratrol through Inhibition of Angiogenesis. Chinese Medical Journal (England), 120, 1672-1677.

[82] Bruner-Tran, K.L., Osteen, K.G., Taylor, H.S., Sokalska, A., Haines, K. and Duleba, A.J. (2011) Resveratrol Inhibits Development of Experimental Endometriosis in Vivo and Reduces Endometrial Stromal Cell Invasiveness in Vitro. Biology of Reproduction, 84, 106-112. http://dx.doi.org/10.1095/biolreprod.110.086744

[83] Rudzitis-Auth, J., Menger, M.D. and Laschke, M.W. (2013) Resveratrol Is a Potent Inhibitor of Vascularization and Cell Proliferation in Experimental Endometriosis. Human Reproduction, 28, 1339-1347. http://dx.doi.org/10.1093/humrep/det031

[84] Dulak, J. and Jozkowicz, A. (2005) Anti-Angiogenic and Anti-Inflammatory Effects of Statins: Relevance to AntiCancer Therapy. Current Cancer Drug Targets, 5, 579-594. http://dx.doi.org/10.2174/156800905774932824

[85] Oktem, M., Esinler, I., Eroglu, D., Haberal, N., Bayraktar, N. and Zeyneloglu, H.B. (2007) High-Dose Atorvastatin Causes Regression of Endometriotic Implants: A Rat Model. Human Reproduction, 22, 1474-1480. http://dx.doi.org/10.1093/humrep/del505 
[86] Bruner-Tran, K.L., Osteen, K.G. and Duleba, A.J. (2009) Simvastatin Protects against the Development of Endometriosis in a Nude Mouse Model. The Journal of Clinical Endocrinology \& Metabolism, 94, 2489-2494. http://dx.doi.org/10.1210/jc.2008-2802

[87] Vitagliano, A., Noventa, M., Quaranta, M. and Gizzo, S. (2015) Statins as Targeted "Magical Pills" for the Conservative Treatment of Endometriosis: May Potential Adverse Effects on Female Fertility Represent the "Dark Side of the Same Coin”? A Systematic Review of Literature. Reproductive Sciences, 23, 415-428. http://dx.doi.org/10.1177/1933719115584446

[88] Novella-Maestre, E., Carda, C., Noguera, I., Ruiz-Saurí, A., García-Velasco, J.A., Simón, C. and Pellicer, A. (2009) Dopamine Agonist Administration Causes a Reduction in Endometrial Implants through Modulation of Angiogenesis in Experimentally Induced Endometriosis. Human Reproduction, 24, 1025-1035. http://dx.doi.org/10.1093/humrep/den499

[89] Schade, R., Andersohn, F., Suissa, S., Haverkamp, W. and Garbe, E. (2007) Dopamine Agonists and the Risk of Cardiac-Valve Regurgitation. The New England Journal of Medicine, 356, 29-38. http://dx.doi.org/10.1056/NEJMoa062222

[90] Delgado-Rosas, F., Gómez, R., Ferrero, H., Gaytan, F., Garcia-Velasco, J., Simón, C. and Pellicer, A. (2011) The Effects of Ergot and Non-Ergot-Derived Dopamine Agonists in an Experimental Mouse Model of Endometriosis. Reproduction, 142, 745-755. http://dx.doi.org/10.1530/REP-11-0223

[91] Gómez, R., Abad, A., Delgado, F., Tamarit, S., Simón, C. and Pellicer, A. (2001) Effects of Hyperprolactinemia Treatment with the Dopamine Agonist Quinagolide on Endometriotic Lesions in Patients with Endometriosis-Associated Hyperprolactinemia. Fertility and Sterility, 95, 882e1-888e1.

[92] Kochar Kaur, K. (2012) A Comparative Study of Treatment of Endometriosis with GnRH agonists vs Dopamine Agonists Caberlin, Statins. Controversies in Obstetrics and Gynaecology, Singapore.

[93] Miyamoto, A., Taniguchi, F., Tagashira, Y., Watanabe, A., Harada, T. and Terakawa, N. (2009) TNF $\alpha$ Gene Silencing Reduced Lipopolysaccharide-Promoted Proliferation of Endometriotic Stromal Cells. American Journal of Reproductive Immunology, 61, 277-285. http://dx.doi.org/10.1111/j.1600-0897.2009.00691.x

[94] Braun, D.P., Ding, J.C. and Dmowski, W.P. (2002) Peritoneal Fluid-Mediated Enhancement of Eutopic and Ectopic Endometrial Cell Proliferation Is Dependent on Tumor Necrosis Factor- $\alpha$ in Women with Endometriosis. Fertility and Sterility, 78, 727-732. http://dx.doi.org/10.1016/S0015-0282(02)03318-6

[95] Yildirim, G., Attar, R., Ficicioglu, C., Karateke, A., Ozkan, F. and Yesildaglar, N. (2011) Etanercept Causes Regression of Endometriotic Implants in a Rat Model. Archives of Gynecology and Obstetrics, 283, 1297-1302. http://dx.doi.org/10.1007/s00404-010-1543-9

[96] Islimye, M., Kilic, S., Zulfikaroglu, E., Topcu, O., Zergeroglu, S. and Batioglu, S. (2011) Regression of Endometrial Autografts in a Rat Model of Endometriosis Treated with Etanercept. European Journal of Obstetrics \& Gynecology and Reproductive Biology, 159, 184-189. http://dx.doi.org/10.1016/j.ejogrb.2011.06.029

[97] Zulfikaroglu, E., Kılıc, S., Islimye, M., Aydin, M., Zergeroglu, S. and Batioglu, S. (2011) Efficacy of Anti-Tumor Necrosis Factor Therapy on Endometriosis in an Experimental Rat Model. Archives of Gynecology and Obstetrics, 283, 799-804. http://dx.doi.org/10.1007/s00404-010-1434-0

[98] Cayci, T., Akgul, E.O., Kurt, Y.G., Ceyhan, T.S., et al. (2011) The Levels of Nitric Oxide and Asymmetric Dimethylarginine in the Rat Endometriosis Model. Journal of Obstetrics and Gynaecology Research, 37, 1041-1047. http://dx.doi.org/10.1111/j.1447-0756.2010.01482.x

[99] Barrier, B.F., Bates, G.W., Leland, M.M., Leach, D.A., Robinson, R.D. and Propst, A.M. (2004) Efficacy of AntiTumor Necrosis Factor Therapy in the Treatment of Spontaneous Endometriosis in Baboons. Fertility and Sterility, 81, 775-779. http://dx.doi.org/10.1016/j.fertnstert.2003.09.034

[100] Falconer, H., Mwenda, J.M., Chai, D.C., et al. (2006) Treatment with Anti-TNF Monoclonal Antibody (c5N) Reduces the Extent of Induced Endometriosis in the Baboon. Human Reproduction, 21, 1856-1862. http://dx.doi.org/10.1093/humrep/del044

[101] Koninckx, P.R., Craessaerts, M., Timmerman, D., Cornillie, F. and Kennedy, S. (2008) Anti-TNF- $\alpha$ Treatment for Deep Endometriosis-Associated Pain: A Randomized Placebo-Controlled Trial. Human Reproduction, 23, 2017-2023. http://dx.doi.org/10.1093/humrep/den177

[102] Lu, D.H., Song, H. and Shi, G. (2013) Anti-TNF- $\alpha$ Treatment for Pelvic Pain Associated with Endometriosis. Cochrane Database of Systematic Reviews, 3, Article No. CD0008088. http://dx.doi.org/10.1002/14651858.cd008088.pub3

[103] Diamond, M.P., Carr, B., Dmowski, P., et al. (2014) Elagolix Treatment for Endometriosis-Associated Pain: Results from a Phase 2, Randomized, Double-Blind, Placebo-Controlled Study. Reproductive Sciences, 21, 363-371. http://dx.doi.org/10.1177/1933719113497292

[104] Kochar Kaur, K. and Allahbadia, G.N. (2015) Medical Management of Leipmyomas-Emphasis for Different Geo- 
graphical Regions. Journal of Gynecology and Neonatal Biology, 1, 1-8. http://dx.doi.org/10.15436/2380-5595.15.010

[105] Chwalisz, K., Perez, M.C., DeManno, D., Winkel, C., Schubert, G. and Elger, W. (2005) Selective Progesterone Receptor Modulator Development and Use in the Treatment of Leiomyomata and Endometriosis. Endocrine Reviews, 26, 423-438. http://dx.doi.org/10.1210/er.2005-0001

[106] Wilkens, J., Chwalisz, K., Han, C., et al. (2008) Effects of the Selective Progesterone Receptor Modulator Asoprisnil on Uterine Artery Blood Flow, Ovarian Activity, and Clinical Symptoms in Patients with Uterine Leiomyomata Scheduled for Hysterectomy. The Journal of Clinical Endocrinology \& Metabolism, 93, 466-471. http://dx.doi.org/10.1210/jc.2008-1104

[107] Kettel, L.M., Murphy, A.A., Morales, A.J., Ulmann, A., Baulieu, E.E. and Yen, S.S. (1996) Treatment of Endometriosis with the Antiprogesterone Mifepristone (RU486). Fertility and Sterility, 65, 23-28. http://dx.doi.org/10.1016/S0015-0282(16)58022-4

[108] Elger, W., Bartley, J., Schneider, B., Kaufmann, G., Schubert, G. and Chwalisz, K. (2000) Endocrine Pharmacological Characterization of Progesterone Antagonists and Progesterone Receptor Modulators with Respect to PR-Agonistic and Antagonistic Activity. Steroids, 65, 713-723. http://dx.doi.org/10.1016/S0039-128X(00)00178-1

[109] Chishima, F., Hayakawa, S., Sugita, K., et al. (2002) Increased Expression of Cyclooxygenase-2 in Local Lesions of Endometriosis Patients. American Journal of Reproductive Immunology, 48, 50-56.

http://dx.doi.org/10.1034/j.1600-0897.2002.01101.x

[110] Schaff, E.A. (2010) Mifepristone: Ten Years Later. Contraception, 81, 1-7. http://dx.doi.org/10.1016/j.contraception.2009.08.004

[111] Im, A. and Appleman, L.J. (2010) Mifepristone: Pharmacology and Clinical Impact in Reproductive Medicine, Endocrinology and Oncology. Expert Opinion on Pharmacotherapy, 11, 481-488. http://dx.doi.org/10.1517/14656560903535880

[112] Donnez, J., Tatarchuk, T.F., Bouchard, P., et al. (2012) Ulipristal Acetate versus Placebo for Fibroid Treatment before Surgery. The New England Journal of Medicine, 366, 409-420. http://dx.doi.org/10.1056/NEJMoa1103182

[113] Donnez, J., Tomaszewski, J., Vázquez, F., et al. (2012) Ulipristal Acetate versus Leuprolide Acetate for Uterine Fibroids. The New England Journal of Medicine, 366, 421-432. http://dx.doi.org/10.1056/NEJMoa1103180

[114] Hayes, E.C. and Rock, J.A. (2002) COX-2 Inhibitors and Their Role in Gynecology. Obstetrical \& Gynecological Survey, 57, 768-780. http://dx.doi.org/10.1097/00006254-200211000-00023

[115] Matsuzaki, S., Canis, M., Darcha, C., Dallel, R., Okamura, K. and Mage, G. (2004) Cyclooxygenase-2 Selective Inhibitor Prevents Implantation of Eutopic Endometrium to Ectopic Sites in Rats. Fertility and Sterility, 82, 1609-1615. http://dx.doi.org/10.1016/j.fertnstert.2004.07.946

[116] Efstathiou, J.A., Sampson, D.A., Levine, Z., Rohan, R.M., Zurakowski, D., Folkman, J., D’Amato, R.J. and Rupnick, M.A. (2005) Nonsteroidal Antiinflammatory Drugs Differentially Suppress Endometriosis in a Murine Model. Fertility and Sterility, 83, 171-181. http://dx.doi.org/10.1016/j.fertnstert.2004.06.058

[117] Olivares, C., Ricci, A., Bilotas, M., Barañao, R.I. and Meresman, G. (2011) The Inhibitory Effect of Celecoxib and Rosiglitazone on Experimental Endometriosis. Fertility and Sterility, 96, 428-433. http://dx.doi.org/10.1016/j.fertnstert.2011.05.063

[118] Olivares, C.N., Bilotas, M.A., Ricci, A.G., Barañao, R.I. and Meresman, G.F. (2013) Anastrozole and Celecoxib for Endometriosis Treatment, Good to Keep Them Apart? Reproduction, 145, 119-126. http://dx.doi.org/10.1530/REP-12-0386

[119] Cobellis, L., Razzi, S., De Simone, S., et al. (2004) The Treatment with a COX-2 Specific Inhibitor Is Effective in the Management of Pain Related to Endometriosis. European Journal of Obstetrics \& Gynecology and Reproductive Biology, 116, 100-102. http://dx.doi.org/10.1016/j.ejogrb.2004.02.007

[120] Burnier, M. (2005) The Safety of Rofecoxib. Expert Opinion on Drug Safety, 4, 491-499. http://dx.doi.org/10.1517/14740338.4.3.491

[121] Lebovic, D.I., Mwenda, J.M., Chai, D.C., Mueller, M.D., Santi, A., Fisseha, S. and D’Hooghe, T. (2007) PPARGamma Receptor Ligand Induces Regression of Endometrial Explants in Baboons: A Prospective, Randomized, Placebo- and Drug-Controlled Study. Fertility and Sterility, 88, 1108-1119. http://dx.doi.org/10.1016/j.fertnstert.2006.12.072

[122] Rubin, G.L., Zhao, Y., Kalus, A.M. and Simpson, E.R. (2000) Peroxisome Proliferator-Activated Receptor Gamma Ligands Inhibit Estrogen Biosynthesis in Human Breast Adipose Tissue: Possible Implications for Breast Cancer Therapy. Cancer Research, 60, 1604-1608.

[123] Ohama, Y., Harada, T., Iwabe, T., Taniguchi, F., Takenaka, Y. and Terakawa, N. (2008) Peroxisome Proliferator-Activated Receptor- $\gamma$ Ligand Reduced Tumor Necrosis Factor- $\alpha$-Induced Interleukin-8 Production and Growth in Endometriotic Stromal Cells. Fertility and Sterility, 89, 311-317. http://dx.doi.org/10.1016/j.fertnstert.2007.03.061 
[124] Wu, Y. and Guo, S.-W. (2009) Peroxisome Proliferator-Activated Receptor-Gamma and Retinoid X Receptor Agonists Synergistically Suppress Proliferation of Immortalized Endometrial Stromal Cells. Fertility and Sterility, 91, 21422147. http://dx.doi.org/10.1016/j.fertnstert.2008.04.012

[125] Lebovic, D.I., Kir, M. and Casey, CL. (2004) Peroxisome Proliferator-Activated Receptor-Gamma Agonist Rosiglitazone Reduces the Size of Experimental Endometriosis in the rat model. Fertility and Sterility, 82, 1008-1013. http://dx.doi.org/10.1016/j.fertnstert.2004.02.148

[126] Aytan, H., Caliskan, A.C., Demirturk, F., Aytan, P. and Koseoglu, D.R. (2007) Peroxisome Proliferator-Activated Receptor-Gamma Agonist Rosiglitazone Reduces the Size of Experimental Endometriosis in the Rat Model. Australian and New Zealand Journal of Obstetrics and Gynaecology, 47, 321-325. http://dx.doi.org/10.1111/j.1479-828X.2007.00744.x

[127] Demirturk, F., Aytan, H., Caliskan, A.C., Aytan, P. and Koseoglu, D.R. (2006) Effect of Peroxisome Proliferator-Activated Receptor- $\gamma$ Agonist Rosiglitazone on the Induction of Endometriosis in an Experimental Rat Model. Journal of the Society for Gynecologic Investigation, 13, 58-62. http://dx.doi.org/10.1016/j.jsgi.2005.10.002

[128] Lebovic, D.I., Mwenda, J.M., Chai, D.C., Santi, A., Xu, X. and D’Hooghe, T. (2010) Peroxisome Proliferator-Activated Receptor- $\gamma$ Receptor Ligand Partially Prevents the Development of Endometrial Explants in Baboons: A Prospective, Randomized, Placebo-Controlled Study. Endocrinology, 151, 1846-1852. http://dx.doi.org/10.1210/en.2009-1076

[129] Onalan, G., Zeyneloglu, H.B. and Bayraktar, N. (2009) Fenofibrate Causes Regression of Endometriotic Implants: A Rat Model. Fertility and Sterility, 92, 2100-2102. http://dx.doi.org/10.1016/j.fertnstert.2009.05.065

[130] Simasko, S.M., Braileanu, G.T., Speth, R.C., Mirando, M.A., Daubert, D. and Hu, J.B. (2002) Angiotensin II Increases Intracellular Calcium Concentration in Pig Endometrial Stromal Cells through Type 1 Angiotensin Receptors, but Does Not Stimulate Phospholipase C Activity or Prostaglandin $\mathrm{F}_{2 \alpha}$ Secretion. Reproduction, Fertility and Development, 14, 199-205. http://dx.doi.org/10.1071/RD02003

[131] Carbajo-Lozoya, J., Lutz, S., Feng, Y., Kroll, J., Hammes, H.P. and Wieland, T. (2012) Angiotensin II Modulates VEGF-Driven Angiogenesis by Opposing Effects of Type 1 and Type 2 Receptor Stimulation in the Microvascular Endothelium. Cellular Signalling, 24, 1261-1269. http://dx.doi.org/10.1016/j.cellsig.2012.02.005

[132] MacKenzie, A. (2011) Endothelium-Derived Vasoactive Agents, AT1 Receptors and Inflammation. Pharmacology \& Therapeutics, 131, 187-203. http://dx.doi.org/10.1016/j.pharmthera.2010.11.001

[133] Nagai, N., Oike, Y., Izumi-Nagai, K., et al. (2006) Angiotensin II Type 1 Receptor-Mediated Inflammation Is Required for Choroidal Neovascularization. Arteriosclerosis, Thrombosis, and Vascular Biology, 26, 2252-2259. http://dx.doi.org/10.1161/01.ATV.0000240050.15321.fe

[134] Tamaki, Y., Nakade, Y., Yamauchi, T., et al. (2013) Angiotensin II Type 1 Receptor Antagonist Prevents Hepatic Carcinoma in Rats with Nonalcoholic Steatohepatitis. Journal of Gastroenterology, 48, 491-503. http://dx.doi.org/10.1007/s00535-012-0651-7

[135] Nenicu, A., Körbel, C., Gu, Y., Menger, M.D. and Laschke, M.W. (2014) Combined Blockade of Angiotensin II Type 1 Receptor and Activation of Peroxisome Proliferator-Activated Receptor- $\gamma$ by Telmisartan Effectively Inhibits Vascularization and Growth of Murine Endometriosis-Like Lesions. Human Reproduction, 29, 1011-1024. http://dx.doi.org/10.1093/humrep/deu035

[136] Fiedler, U. and Augustin, H.G. (2006) Angiopoietins: A Link between Angiogenesis and Inflammation. Trends in Molecular Medicine, 27, 552-558. http://dx.doi.org/10.1016/j.it.2006.10.004

[137] Ramano, M. (2010) Lipoxin and Aspirin-Triggered Lipoxins. The Scientific World Journal, 10, 1048-1064. http://dx.doi.org/10.1100/tsw.2010.113

[138] Baker, N., O’Meara, S.J., Scannell, M., Maderna, P. and Godson, C. (2009) Lipoxin A4: Anti-Inflammatory and AntiAngiogenic Impact on Endothelial Cells. The Journal of Immunology, 182, 3819-3826. http://dx.doi.org/10.4049/jimmunol.0803175

[139] Hao, H., Liu, M., Wu, P., Cai, L., Tang, K., Yi, P., Li, Y., Chen, Y. and Ye, D. (2011) Lipoxin A 4 and Its Analog Suppress Hepatocellular Carcinoma via Remodeling Tumor Microenvironment. Cancer Letters, 309, 85-94. http://dx.doi.org/10.1016/j.canlet.2011.05.020

[140] Xu, Z., Zhao, F., Lin, F., Chen, J. and Huang, Y. (2012) Lipoxin A4 Inhibits the Development of Endometriosis in Mice: The Role of Anti-Inflammation and Anti-Angiogenesis. American Journal of Reproductive Immunology, 67, 491-497. http://dx.doi.org/10.1111/j.1600-0897.2011.01101.x

[141] Guba, M., von Breitenbuch, P., Steinbauer, M., et al. (2002) Rapamycin Inhibits Primary and Metastatic Tumor growTh by Antiangiogenesis: Involvement of Vascular Endothelial Growth Factor. Nature Medicine, 8, 128-135. http://dx.doi.org/10.1038/nm0202-128

[142] Vlahos, N.F., Gregoriou, O., Deliveliotou, A., et al. (2010) Effect of Pentoxifylline on Vascular Endothelial Growth 
Factor C and flk-1 Expression on Endometrial Implants in the Rat Endometriosis Model. Fertility and Sterility, 93, 1316-1323. http://dx.doi.org/10.1016/j.fertnstert.2008.10.056

[143] Olive, D.L., Lindheim, S.R. and Pritts, E.A. (2004) New Medical Treatments for Endometriosis. Best Practice \& Research: Clinical Obstetrics \& Gynecology, 18, 319-328. http://dx.doi.org/10.1016/j.bpobgyn.2004.03.005

[144] Kamencic, H. and Thiel, J.A. (2008) Pentoxifylline after Conservative Surgery for Endometriosis: A Randomized, Controlled Trial. Journal of Minimally Invasive Gynecology, 15, 62-66. http://dx.doi.org/10.1016/j.jmig.2007.07.018

[145] Alborzi, S., Ghotbi, S., Parsanezhad, M.E., Dehbashi, S., Alborzi, S. and Alborzi, M. (2007) Pentoxifylline Therapy after Laparoscopic Surgery for Different Stages of Endometriosis: A Prospective, Double-Blind, Randomized, Placebo-Controlled Study. Journal of Minimally Invasive Gynecology, 44, 54-58. http://dx.doi.org/10.1016/j.jmig.2006.06.024

[146] Balasch, J., Creus, M., Fábregues, F., et al. (1997) Pentoxifylline versus Placebo in the Treatment of Infertility Associated with Minimal or Mild Endometriosis: A Pilot Randomized Clinical Trial. Human Reproduction, 12, $2046-2050$. http://dx.doi.org/10.1093/humrep/12.9.2046

[147] Creus, M., Fábregues, F., Carmona, F., del Pino, M., Manau, D. and Balasch, J. (2008) Combined Laparoscopic Surgery and Pentoxifylline Therapy for Treatment of Endometriosis-Associated Infertility: A Preliminary Trial. Human Reproduction, 23, 1910-1916. http://dx.doi.org/10.1093/humrep/den167

[148] Lu, D., Song, H., Li, Y., Clarke, J. and Shi, G. (2012) Pentoxifylline for Endometriosis. Cochrane Database of Systematic Reviews, 1, Article No. CD00767772. http://dx.doi.org/10.1002/14651858.CD007677.pub3

[149] Leconte, M., Santulli, P., Chouzenoux, S., et al. (2015) Inhibition of MAPK and VEGFR by Sorafenib Controls the Progression of Endometriosis. Reproductive Sciences, 22, 1171-1180. http://dx.doi.org/10.1177/1933719115592708

[150] Taylor, R.N., Kane, M.A. and Sidell, N .(2015) Pathogenesis of Endometriosis: Roles of Retinoids and Inflammatory Pathways. Seminars in Reproductive Medicine, 33, 246-256. http://dx.doi.org/10.1055/s-0035-1554920 


\section{Abbreviations}

$\mathrm{NF} \kappa \mathrm{B}$-Nuclear factor kappa B;

MIF-Macrophage migration inhibiting factor;

MCP1-Monocyte chemoattractant protein;

GM-CSF-Granulocyte macrophage colony stimulating factor;

TNF- $\alpha$ - Tumour necrosis factor alpha;

NO-Nitricoxide;

VEGF-Vascular endothelial growth factor;

IL-4L-Interleukin 4, 6, 8;

IL-17A-Interleukin 17A

Treg-Regulatory T cells;

NK Cells-Natural killer cells;

MMP_Matrix metalloproteinase;

ICAM - Intercellular adhesion molecule;

VCAM-Vascular cell adhesion molecule;

VEGFR_-Vascular endothelial growth factor receptor;

CAM-Chorioallantoic membrane;

bFGF_-basic fibroblast growth factor;

EGVEGF/PROK1—prokineticin 1;

ECM-Ectracellular matrix;

PR-Progesterone receptor;

HOXA10-Homebox10;

ADMA-Asymmetric dimethyl arginine;

mAb-monoclonal antibody;

$\mathrm{TRP}-\mathrm{TNF} \alpha$ binding protein;

SPRM - Selective progesterone receptor modulators;

COX1/2-Cyclooxygenase inhibitors 1 and 2;

HIF-1 $\alpha$ - Hypoxia inducible factor 1 -alpha;

PPAR gamma-Peroxisome proliferator activated receptor gamma agonists;

PCOS-Poly cystic ovarian syndrome;

Hesc-Human endometrial stromal cells;

AT1R-Angiotensinreceptor1 agonist;

CXCR-CXC type chemokine receptor

AKT-Active human protein kinase;

ERK-Extracellular signal regulated kinase;

FAK-Focal adhesion kinase;

FGF-Fibroblast growth factor;

FGFR - Fibroblast growth factor receptor;

HIF-Hypoxia inducible factor;

HRE_-Hypoxia response element;

MAPK-Mitogen activated protein kinase;

NOS-Nitric oxide synthase;

p300/CBP_p300/CREB binding protein;

PDGF-Platelet derived growth factor;

PDGFR-Platelet derived growth factor receptor;

PI3K-Phosphatidylinositol-3-kinase;

PLC $\gamma$-Phospholipase C gamma;

RAS-Rat sarcoma GTPase;

Src-Tyrosine kinase;

Ub-Ubiquitin;

VHL_-Von Hippel-Lindad protein. 